Article

\title{
Hydrochemical Characteristics of Arsenic in Shallow Groundwater in Various Unconsolided Sediment Aquifers: A Case Study in Hetao Basin in Inner Mongolia, China
}

\author{
Zizhao Cai ${ }^{1,2}$, Lingxia Liu ${ }^{2,3, *}$, Wei $\mathrm{Xu}{ }^{4}$, Ping $\mathrm{Wu}^{5}$ and Chuan $\mathrm{Lu}^{2}$ \\ 1 School of Water and Environment, Chang'an University, Yanta Road 126, Xi'an 710054, China; \\ caizizhao@mail.cgs.gov.cn \\ 2 The Institute of Hydrogeology and Environmental Geology, Chinese Academy of Geological Sciences, \\ Shijiazhuang 050061, China; luchuancn@163.com \\ 3 School of Environmental Studies, China University of Geosciences, Wuhan 430074, China \\ 4 Hebei Prospecting Institute of Hydrogeology and Engineering Geology, Shijiazhuang 050021, China; \\ xu30874959@163.com \\ 5 Institute of Hydrogeology and Environmental Geology of Ningxia, Yinchuan 750011, China; \\ pushmyluck@163.com \\ * Correspondence: 1lingxia2004@163.com
}

Citation: Cai, Z.; Liu, L.; Xu, W.; Wu, P.; Lu, C. Hydrochemical Characteristics of Arsenic in Shallow Groundwater in Various

Unconsolided Sediment Aquifers: A Case Study in Hetao Basin in Inner Mongolia, China. Water 2022, 14, 669. https://doi.org/10.3390/w14040669

Academic Editor: Daniel D. Snow

Received: 28 November 2021

Accepted: 17 February 2022

Published: 21 February 2022

Publisher's Note: MDPI stays neutral with regard to jurisdictional claims in published maps and institutional affiliations.

Copyright: (C) 2022 by the authors. Licensee MDPI, Basel, Switzerland. This article is an open access article distributed under the terms and conditions of the Creative Commons Attribution (CC BY) license (https:/ / creativecommons.org/licenses/by/ $4.0 /)$.

\begin{abstract}
This study focused on the entire Hetao Basin, which can fall into four hydrogeological units, the Houtao Plain, Sanhuhe Plain, Hubao Plain, and South Bank Plain of the Yellow River, all of which are under different geological and environmental conditions. To systematically investigate the hydrochemical characteristics and spatial distribution of high-As groundwater (As $>10 \mu \mathrm{g} / \mathrm{L}$ ), 974 samples were collected from shallow groundwater. As indicated from the results, high-As groundwater had an extensive distribution, and its spatial distribution in the four hydrogeological units exhibited significant variability. Three concentrated distribution areas were reported with high-As groundwater, which were all in the discharge areas of groundwater, and the arsenic contents in the groundwater were found to exceed $50 \mu \mathrm{g} / \mathrm{L}$. The hydrochemical types of high-As groundwater in the HT Plain and the SHH Plain consisted of $\mathrm{HCO}_{3} \mathrm{SO}_{4} \cdot \mathrm{Cl}$ for anions and $\mathrm{Na}$ for cations, while those in the other two plains included $\mathrm{HCO}_{3}$ for anions as well as $\mathrm{Na} \cdot \mathrm{Mg} \cdot \mathrm{Ca}$ for cations. According to the $\mathrm{pH}$ values, the groundwater was weakly alkaline in the areas with high-As groundwater, and arsenic primarily existed as arsenite. Furthermore, high-As groundwater in the Hetao Basin was characterized by high contents of $\mathrm{Fe}$ (mean value of $2.77 \mathrm{mg} / \mathrm{L}$ ) and $\mathrm{HCO}_{3}{ }^{-}$(mean value of $460 \mathrm{mg} / \mathrm{L}$ ) and a low relative concentration of $\mathrm{SO}_{4}{ }^{2-}$ (average value of $310 \mathrm{mg} / \mathrm{L}$ ). This study did not identify any significant correlation between groundwater arsenic and other ions (e.g., $\mathrm{Fe}^{2+}, \mathrm{Fe}^{3+}, \mathrm{HCO}^{3-}, \mathrm{SO}_{4}{ }^{2-}$, $\mathrm{NO}_{2}{ }^{-}$and $\mathrm{NO}_{3}{ }^{-}$) in the entire Hetao Basin over a wide range of hydrogeological units. The results remained unchanged after the four hydrogeological units were analyzed. The special sedimentary environment evolution of the Hetao Basin was found as the prerequisite for the formation of higharsenic groundwater. Furthermore, groundwater runoff conditions and hydrogeochemical processes in the basin were indicated as the factors controlling the formation of high-arsenic groundwater.
\end{abstract}

Keywords: high-As groundwater; shallow groundwater; geological environment; geochemistry; correlation; Hetao Basin

\section{Introduction}

High As groundwater has been reported as one of the most serious geological environmental issues facing the international community [1,2]. Drinking contaminated water such as high-As groundwater can directly jeopardize human health [3-8], which has aroused great interest from a wide range of organizations in the international community and numerous national government agencies $[9,10]$. Endemic arsenic poisoning attributed to drinking high-As groundwater has frequently occurred worldwide in places such as India, 
Bangladesh, Vietnam and Thailand in Asia, Germany, Chile, Brazil, Argentina, Italy, and The United Kingdom in Europe, and the United States and Canada in America [11-20].

Several natural and anthropogenic sources are responsible for the contamination of As in groundwater. As occurs as a major constituent in more than 200 minerals, and the desorption and dissolution of naturally occurring As-bearing minerals are generally considered the principal source of As contamination in groundwater [21,22]. Arsenopyrite (FeAsS) is the most abundant As-containing mineral that commonly exists in anaerobic environments and can also be found in different concentrations in various rock-forming minerals like sulfide, oxide, phosphate, carbonate and silicate [23]. Moreover, other secondary As minerals (e.g., scorodite, $\mathrm{FeAsO}_{4} 2 \mathrm{H}_{2} \mathrm{O}$ ) can contain the pollutant as a main or trace component [24,25].

The Hetao Basin of Inner Mongolia in China has been found to be a highly typical area of high-As groundwater [26,27]. Due to drinking high-As groundwater, arsenic poisoning patients were reported in the early 1990s [28]. The As-affected area reached over $3000 \mathrm{~km}^{2}$. The affected population exceeded 1 million, 400 thousand people drank high-As groundwater (As $>50 \mu \mathrm{g} / \mathrm{L}$ ), and over 2000 residents of the 776 villages were confirmed as arsenic patients [29].

On the whole, groundwater As in the Hetao Basin has been considered to occur naturally in Later Pleistocene-Holocene alluvial-lacustrine aquifers (generally ranging from 10 to $50 \mathrm{~m}$ ) [30-32]. In the typical arsenic poisoning area of the HT Plain, studies on the arsenic morphology and trace element concentration in groundwater have basically clarified the causes of arsenic enrichment in groundwater and its effect on arsenic poisoning [33,34]. Smedley et al. investigated the migration of As and other trace elements in the aquifer of the alluvial plain of Hohhot Basin in Inner Mongolia and highlighted that the high concentrations of As in groundwater were dependent on the strong reduction environment, as reflected in the high content of soluble $\mathrm{Fe}, \mathrm{Mn}, \mathrm{NH}_{4}-\mathrm{N}$ and DOC in groundwater [23]. When initially studying the migration, enrichment and transformation of As in arsenicaffected areas of the Hetao Plain, Lin Nianfeng et al. highlighted that clay soil and humus soil could help enrich As and reduction environments could covert $\mathrm{As}^{5+}$ into $\mathrm{As}^{3+}$ [35]. Guo Huaming et al. performed an indoor microbial leaching experiment through the in situ collection of sediments and indigenous microorganisms from a high-As aquifer in the Hetao Plain, Inner Mongolia. As indicated by the above studies, the release and transformation processes of arsenic as impacted by indigenous microorganisms consisted of the release of $\mathrm{As}(\mathrm{V})$ in sediments, the reduction of $\mathrm{As}(\mathrm{V})$ in solution, as well as the release of $\mathrm{As}(\mathrm{III})$ in sediments. The reductive dissolution of Fe/Mn oxide minerals under the action of indigenous microorganisms was highlighted as a major cause of arsenic release in sediments [31]. Gao Cunrong et al. explored the distribution and hydrochemical characteristics exhibited by high-As groundwater in the riverfront area of the Hetao Plain and highlighted that the high-As groundwater was largely distributed in the depositional center of the Hetao Plain and in small patches locally. They also found that the arsenic content in groundwater a short distance inland varied significantly. The over-standard rate of iron content in groundwater in the high-As areas significantly exceeded the nonarsenic-rich area, and the formation of high-As groundwater in this area was considered to be highly dependent on the characteristics exhibited by the sedimentary environment and sediments $[36,37]$.

Numerous scholars in and outside China have conducted considerable investigations and research work in the HT Plain and the HB Plain. Most of the relevant studies were local and did not comprehensively assess the regional spatial distribution and formation mechanisms of high-As groundwater. Besides, arsenic in natural water bodies shows significantly high spatial variability [23], and the conclusions of the local studies are generally difficult to verify in the region. However, the formation and evolution mechanisms of high-As groundwater should be explored from the time and space perspectives to select an appropriate typical area or a geological section. 
This study focused on the entire Hetao Basin, which fell into four hydrogeological units under the different geological and environmental conditions (i.e., Houtao Plain (HT Plain), Sanhuhe Plain (SHH Plain), Hubao Plain (HB Plain), and South Bank Plain of Yellow River (SBYR Plain)). Considerable groundwater samples have been collected, especially samples from the SHH Plain and SBYR Plain, which have not yet been studied, and the distribution and hydrochemical characteristics exhibited by shallow high-As groundwater have been systematically studied.

\section{Study Area}

\subsection{Geographical Conditions}

The Hetao Basin is located in the central and western regions of the Inner Mongolia Autonomous Region $\left(106^{\circ} 07^{\prime} \sim 112^{\circ} 15^{\prime}\right.$ E, $40^{\circ} 10^{\prime} \sim 41^{\circ} 27^{\prime}$ N, Figure 1), stretching from the Ulanbuh Desert in the west to the west foot of the Manhan Mountain in the east, as well as from the Yinshan Mountains in the north to the Ordos Plateau in the south, which takes up a total area of nearly $3.2 \times 104 \mathrm{~km}^{2}$. It has been recognized as a vital grain production base in China and the most developed socio-economic area in the Inner Mongolia Autonomous Region, involving Hohhot (the capital city of the Inner Mongolia Autonomous Region) and Baotou (the largest industrial city in the Autonomous Region). Such an area is characterized by an average annual temperature of $6.5-7.8^{\circ} \mathrm{C}$, with an average monthly maximal temperature of $22.4^{\circ} \mathrm{C}$ (July) and an average monthly minimum temperature of $-12.0^{\circ} \mathrm{C}$ (January). On average, the annual precipitation is $245.5 \mathrm{~mm}$, and the annual precipitation of the eastern part exceeds the western part. The evaporation in the eastern part is $2185.2 \mathrm{~mm}$, lower than that of the western part [38,39]. The Yellow River is known as the only perennial river in the study area, flowing from the west to the east via the whole area, and the other large seasonal rivers consist of the Dahei River and the Kundulun River [40].

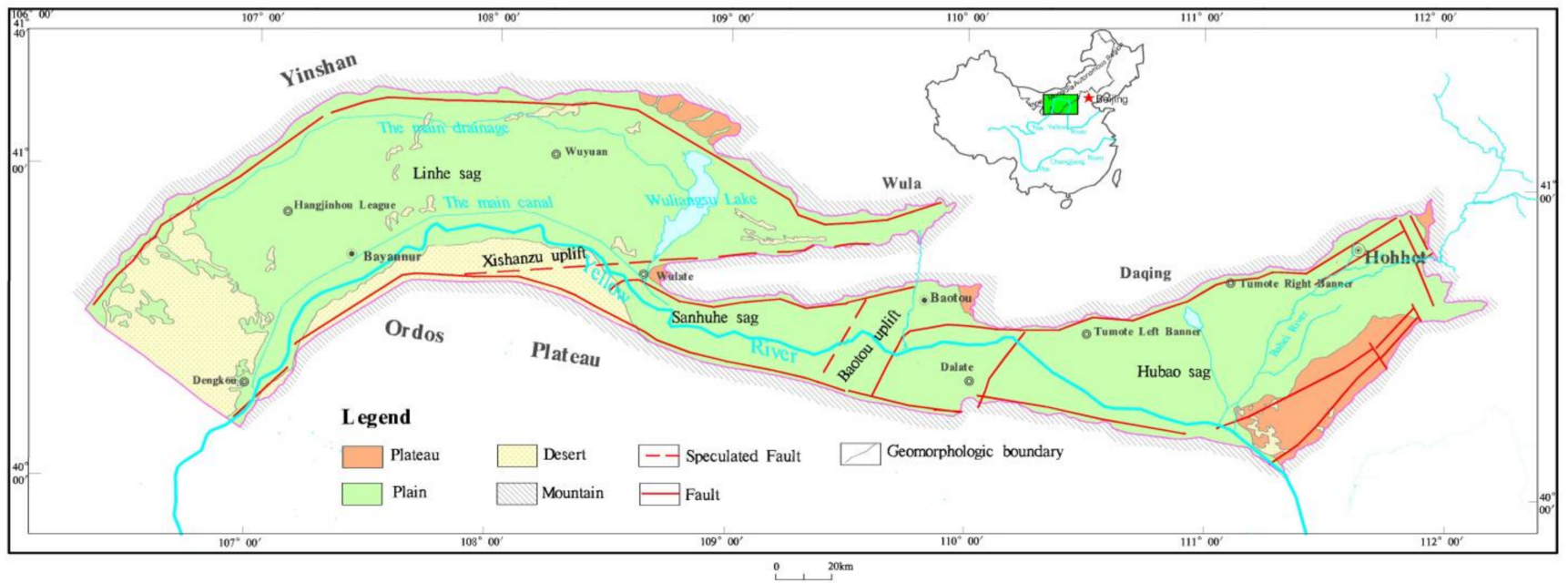

Figure 1. Geologic and geomorphologic map of the Hetao Basin.

\subsection{Geological Backgrounds}

The Hetao Basin can be divided into four geomorphic zones: mountains, plateaus, plains and desert. Spatially, the Hetao Basin exhibits a geologic structure of "three sags and two uplifts", and its tectonic pattern basically regulates the stratigraphic framework and sedimentary (phase) pattern of the Quaternary sedimentary sequence, as well as the spatial distribution of the sedimentary system [40]. It can fall into the Linhe sag area, Xishanzui uplift area, Sanhuhe sag area, Baotou uplift area, as well as the Hubao sag area (Figure 1).

The Quaternary strata can be split into four rock formations from top to bottom. The first rock formation $\left(\mathrm{Q}_{3-4}\right)$ is composed of grayish-yellow, light gray alluvial mediumfine sand, silty-fine sand mixed with medium-coarse sand, alluvial silty-fine sand, fine sand, silty clay, and other interbeds exhibiting different thicknesses with local muddy clay 
intercalation and thicknesses of 10-260 m. Overall, the second rock formation $\left(\mathrm{Q}_{2}{ }^{2}\right)$ covers black-gray and grayish-brown limnetic facies mud, muddy clay, muddy silty-fine sand and silty clay, with local multilayers of mirabilite. Such a formation is extensively and continuously distributed in the basin and pertains to a landmark formation significantly correlated with the formation of high-As groundwater with thicknesses of 30-170 $\mathrm{m}[26,27]$. The third rock formation $\left(\mathrm{Q}_{2}{ }^{1}\right)$ comprises brown-yellow, light gray and gray-brown alluvial silty-fine sand, medium-fine sand, medium-coarse sand and thick layers of clay silt, as well as silty clay interbed, with local light grey muddy clay, which is the main confined aquifer with thicknesses of 20-319 m. The fourth rock formation $\left(Q_{1}\right)$ covers the lacustrine facies-based gray, grayish-brown and grayish-green clay silt, silty clay and silty-fine sand, and medium-fine sand interbed. The bottom is sandy gravel, which is not reached [38-40].

\subsection{Hydrogeological Conditions}

On the whole, 48 hydrogeological profiles were prepared with the collected data of over 1300 boreholes, dynamic groundwater monitoring data of 20 years and the water level data in 4 periods from 2009 to 2010, illustrating the hydrogeological conditions of the study area and laying the conditions for analyzing high-As groundwater.

The shallow aquifer of the HT Plain in the piedmont alluvial-pluvial fan in the north comprises Holocene and Epipleistocene proluvium with gravel and medium-coarse sand containing gravel, 10-130 m thick [23]. The water level varies from $20-40 \mathrm{~m}$ at the top of the fan group to $3-5 \mathrm{~m}$ at the front edge. The alluvial lacustrine plain of the Yellow River in the south primarily covers Holocene-Epipleistocene alluvial lacustrine facies medium-fine sand, fine sand and silty-fine sand, which is dominated by semi-confined water with local phreatic water [31]. The thickness exhibited by the aquifer increases from $20-80 \mathrm{~m}$ in SE to $100-240 \mathrm{~m}$ in NW. The burial depth of groundwater level is shallow, generally ranging from $3-10 \mathrm{~m}$. On the whole, the shallow groundwater is recharged by the lateral runoff, the underground flow in the valleys, the atmospheric precipitation, and the infiltration of irrigation with water from the Yellow River in the northern bedrock mountain area. In the northern piedmont fan zone, the groundwater is largely supplied by the north-south runoff, and the runoff conditions deteriorate in the foreland depression. In the alluvial plain of the Yellow River in the south, the groundwater flows as SW-NE runoff. The shallow groundwater forms a drainage zone by complying with the main drainage line and eventually flows as runoff eastward to the Wuliangsuhai Lake [38-40].

The shallow aquifer in the SHH Plain mostly comprises Holocene and Epipleistocene medium-fine sand and silty-fine sand [41,42]. The local river channel covers sandy gravel. From the north to the bank along the Yellow River, the thickness of the aquifer tends to decrease from 30-40 $\mathrm{m}$ to $20-30 \mathrm{~m}$, and the groundwater depth declines from 5-10 m to 1-3 $\mathrm{m}$. The groundwater is primarily recharged by the surface runoff, the subsurface flow, atmospheric precipitation and irrigation infiltration while flowing from NW to SE as runoff to the east of Xisanzui. It flows as runoff from the northeast to the southwest to the east of Baotou, which is mostly discharged by mining and lateral discharge to the Yellow River [41,42].

The shallow aquifers in the eastern and western regions in the HB Plain exhibit different characteristics attributed to a wide range of sedimentary environments. The aquifer in the eastern region is the phreatic water-micro-confined aquifer of the piedmont plain of the Dahei River. The compositions vary from proluvium and alluvium gravels, pebbles and sandy gravels gradually to alluvial gravels, medium-coarse sand and fine silty sand to the lake basin. From the west to the east, the groundwater level is altered from nearly $15 \mathrm{~m}$ to approximately $5 \mathrm{~m}$, and the thickness of the aquifer is up-regulated from $10 \mathrm{~m}$ to $27 \mathrm{~m}$ [43]. The aquifer in the western region, composed of Holocene and Epipleistocene medium-fine sand and silty-fine sand, refers to the phreatic water-microconfined aquifer of the alluvial lacustrine plain of the Yellow River [44]. The thickness of the aquifer varies from $80-100 \mathrm{~m}$ in the northwest to $20-40 \mathrm{~m}$ in the east. The burial depth of water level is $5-10 \mathrm{~m}$ close to the front of the mountain and $2-5 \mathrm{~m}$ generally following the 
Yellow River and in the eastern region [45]. Laterally, the groundwater is recharged by the bedrock fissure water in some sections, subsurface flow of river valleys and surface runoff, as well as precipitation and irrigation infiltration in the mountainous area. Furthermore, the groundwater flows as runoff from the northeast to the southwest in the eastern region and flows as runoff from the northwest to the southeast and is discharged through mining, evaporation and lateral discharge to a canal for water release of Hasuhai Lake and the Yellow River.

The shallow aquifer of the SBYR Plain covers Holocene-Epipleistocene proluvium and alluvial lacustrine silty-fine sand, fine sand and silty sand [26,27]. The thickness of the aquifer rises from less than $50 \mathrm{~m}$ in the south to 50-100 $\mathrm{m}$ in the north, and it exceeds $100 \mathrm{~m}$ in local areas. In most areas, the burial depth of the groundwater level is less than $5 \mathrm{~m}$, generally $5-15 \mathrm{~m}$ in the front of hills. The groundwater is largely recharged by atmospheric precipitation, lateral infiltration in the hilly southern area, infiltration of the valleys, and infiltration of the irrigation canals for water diversion from the Yellow River. The groundwater is mainly recharged from precipitation, runoffs from hills in the south, and water in irrigation channels from the Yellow River. It is discharged by evaporation, manual mining, and lateral seepage to the Yellow River [40-42].

\section{Materials and Methods}

\subsection{Collection of Samples}

The samples were collected from the HT Plain and the SHH Plain in September and October 2009 and from the HB Plain and the SBYR Plain from June to August 2010. A total of 974 sets of samples were collected in total from the shallow groundwater, including 450 from the HT Plain, 56 from the SHH Plain, 278 from the HB Plain, as well as 190 from the SBYR Plain. The sampling points were evenly distributed (Figure 2). $40 \mathrm{~mL}$ arsenic samples, $250 \mathrm{~mL}$ iron samples, $250 \mathrm{~mL}$ trace element samples and $1500 \mathrm{~mL}$ samples for full analysis were collected from the respective sampling points. After water temperature, electrical conductivity (EC), $\mathrm{pH}$, and Eh were stable, groundwater samples were taken. All samples were membrane filtered $(0.45 \mu \mathrm{m})$ in the field. The samples used for As speciation analysis were stored in new but pre-rinsed HDPE bottles (Nalgene) after adding 0.25 MEDTA. The filtered samples were then acidified to $\mathrm{pH} 1$ by the addition of ultra-pure $\mathrm{HCl}$ for major and trace element analysis. Protective agents were also added to other samples, i.e., $2.5 \mathrm{~mL}$ of 1:1 sulfuric acid solution and $0.5 \mathrm{~g}$ of ammonium sulfate to iron samples, as well as $2.5 \mathrm{~mL}$ of 1:1 nitric acid solution to trace element samples. Except for the samples intended for full analyses, the other samples were stored in a freezer with the temperature regulated at $4{ }^{\circ} \mathrm{C}$ and analyzed within 5 days.

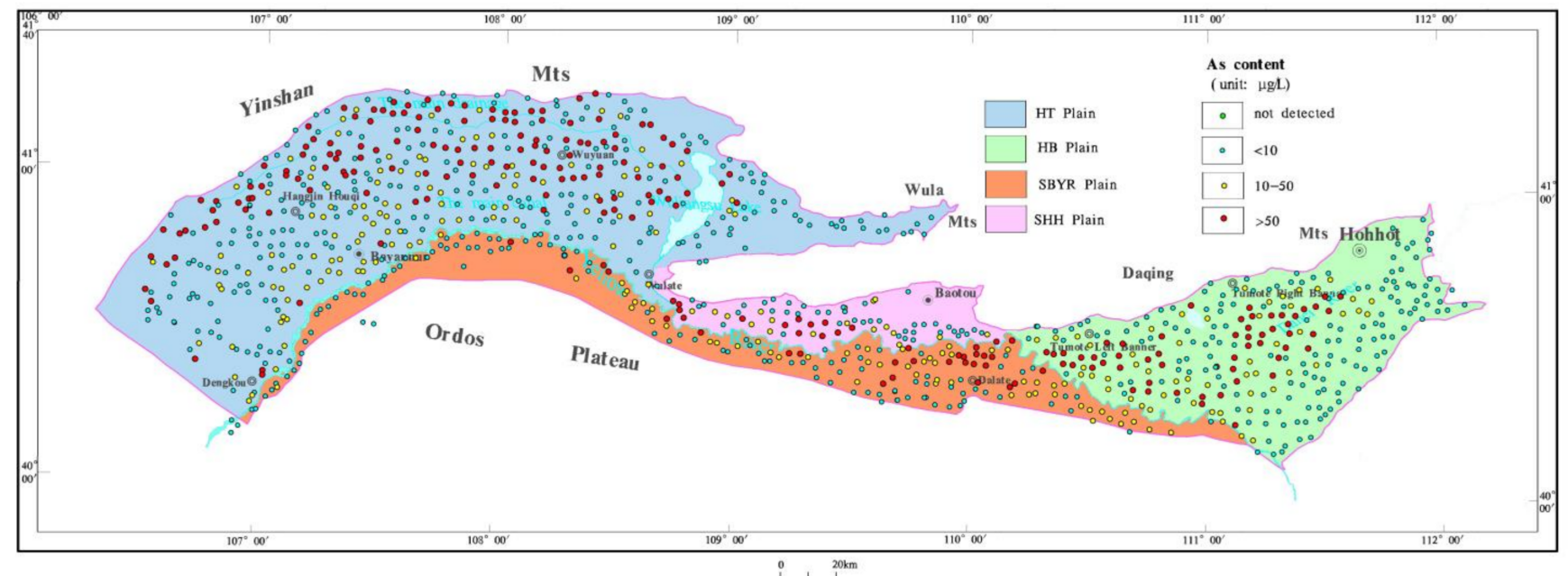

Figure 2. Arsenic content distribution of groundwater samples in the Hetao Basin. 


\subsection{Analytical Method}

The hydrochemical indexes of high-As groundwater ( $\mathrm{pH}$ value, conductivity, dissolved oxygen and oxidation-reduction potential) were determined in the field by employing American Hach sensION2 and Hach LDO TM HQ 10 portable testers. The $\mathrm{NO}_{3}{ }^{-}$and $\mathrm{SiO}_{2}$ of groundwater were determined by adopting the UV8500 UV-vis spectrophotometer. Cations (e.g., $\mathrm{Ca}, \mathrm{Mg}, \mathrm{Na}, \mathrm{K}, \mathrm{Fe}, \mathrm{Mn}, \mathrm{Sr}, \mathrm{B}$ and $\mathrm{Ba}$ ) were determined with PHS-2C ICP-AES. Fe elements were examined in $\mathrm{Fe}^{2+}$ and $\mathrm{Fe}^{3+}$. Se was determined under an XGY-1012 atomic fluorescence spectrometer. $\mathrm{As}^{3+}$ and $\mathrm{As}^{5+}$ were tested with XGY-1012 atomic fluorescence spectrometer, respectively. Other elements were analyzed by using the standard methods. To ensure the quality of the test data of groundwater samples, $5 \%$ repeated samples were added, and the error of all repeated samples was less than $5 \%$. The samples were tested by the Key Laboratory of Groundwater Mineral Water and Environmental Supervising and Testing Center, Ministry of Land and Resources of the PRC.

\section{Results}

\subsection{Content and Regional Distribution of Arsenic in Groundwater}

The high-As samples of shallow groundwater took up $47.33 \%$ of the total samples, and the average concentration of arsenic in the groundwater reached $45.58 \mu \mathrm{g} / \mathrm{L}$. Only 18 samples had lower contents than the detection limit $(<0.1 \mu \mathrm{g} / \mathrm{L})$, and the detection rate reached $98.15 \%$ (Table 1 ). According to the above table, the high-As groundwater in the Hetao Basin was widely distributed. The high-As groundwater was extensively distributed in the four hydrogeological units, and it achieved the widest distribution in the HT Plain. The high-As groundwater samples accounted for $53.78 \%$ of the 450 sample sets. The maximal arsenic content was $916.70 \mu \mathrm{g} / \mathrm{L}$, and the arsenic content in groundwater was $64.13 \mu \mathrm{g} / \mathrm{L}$ on average, which was the highest in the whole region. Only three groundwater samples contained arsenic contents lower than the detection limit $(<0.1 \mu \mathrm{g} / \mathrm{L})$, and the detection rate took up $99.33 \%$. The SHH Plain was the minimum. Though there were only 56 sets of samples, the detection rate was $100 \%$. The average arsenic content reached $40.64 \mu \mathrm{g} / \mathrm{L}$, only smaller than the HT Plain. The average arsenic content in the groundwater of the SBYR Plain was the minimum $(22.51 \mu \mathrm{g} / \mathrm{L})$ among the four hydrogeological units. Furthermore, the number of high-As groundwater samples in the HB Plain accounted for $38.49 \%$ of the total number of samples, which was the minimum in the whole region.

Table 1. Statistical table of arsenic content in shallow groundwater of the Hetao Basin.

\begin{tabular}{|c|c|c|c|c|c|c|c|}
\hline & Area $\left(\mathrm{km}^{2}\right)$ & Number & $0.1 \mu \mathrm{g} / \mathrm{L}(\%)$ & $>10 \mu \mathrm{g} / \mathrm{L}(\%)$ & Mean $(\mu \mathrm{g} / \mathrm{L})$ & Medium ( $\mu \mathrm{g} / \mathrm{L})$ & $\operatorname{Max}(\mu \mathrm{g} / \mathrm{L})$ \\
\hline HT Plain & 13,880 & 450 & 99.33 & 53.78 & 64.13 & 14.44 & 916.7 \\
\hline SHH Plain & 1623 & 56 & 100 & 51.79 & 40.64 & 12.48 & 615.4 \\
\hline HB Plain & 11,382 & 278 & 95.32 & 38.49 & 32.31 & 3.76 & 398.9 \\
\hline SBYR Plain & 4995 & 190 & 99.47 & 43.68 & 22.51 & 6.31 & 238.3 \\
\hline Hetao Baisn & 31,880 & 974 & 98.15 & 47.33 & 45.58 & 7.95 & 916.7 \\
\hline
\end{tabular}

As revealed by the distribution of high-As groundwater points (Figure 1), high-As groundwater in the Hetao Basin was distributed throughout the region with an extremely uneven spatial distribution. The variability of arsenic contents in groundwater was analyzed by using SPSS (IBM, Armonk, NY, USA). The spatial variation coefficient of arsenic content was 2.07, and the variation coefficient of arsenic content in groundwater of the four hydrogeological units ranged from 1.57 to 2.18 , which demonstrated that the spatial variability of arsenic content in groundwater was significantly large in the whole basin and the four hydrogeological units. There were three relatively concentrated distribution areas of high-As groundwater in the whole basin (Figure 3), with arsenic contents of underground water usually larger than $50 \mu \mathrm{g} / \mathrm{L}$. The mentioned areas consisted of (1) an intersection zone of the front edge of the piedmont alluvial-pluvial fan of the HT Plain and the alluvial lacustrine plain of the Yellow River, (2) both sides of the modern river channel of the Yellow 
River from the HT Plain to the SHH Plain and the HB Plain, as well as (3) the central region of the HB Plain, located in the middle east of Tumd Left Banner.

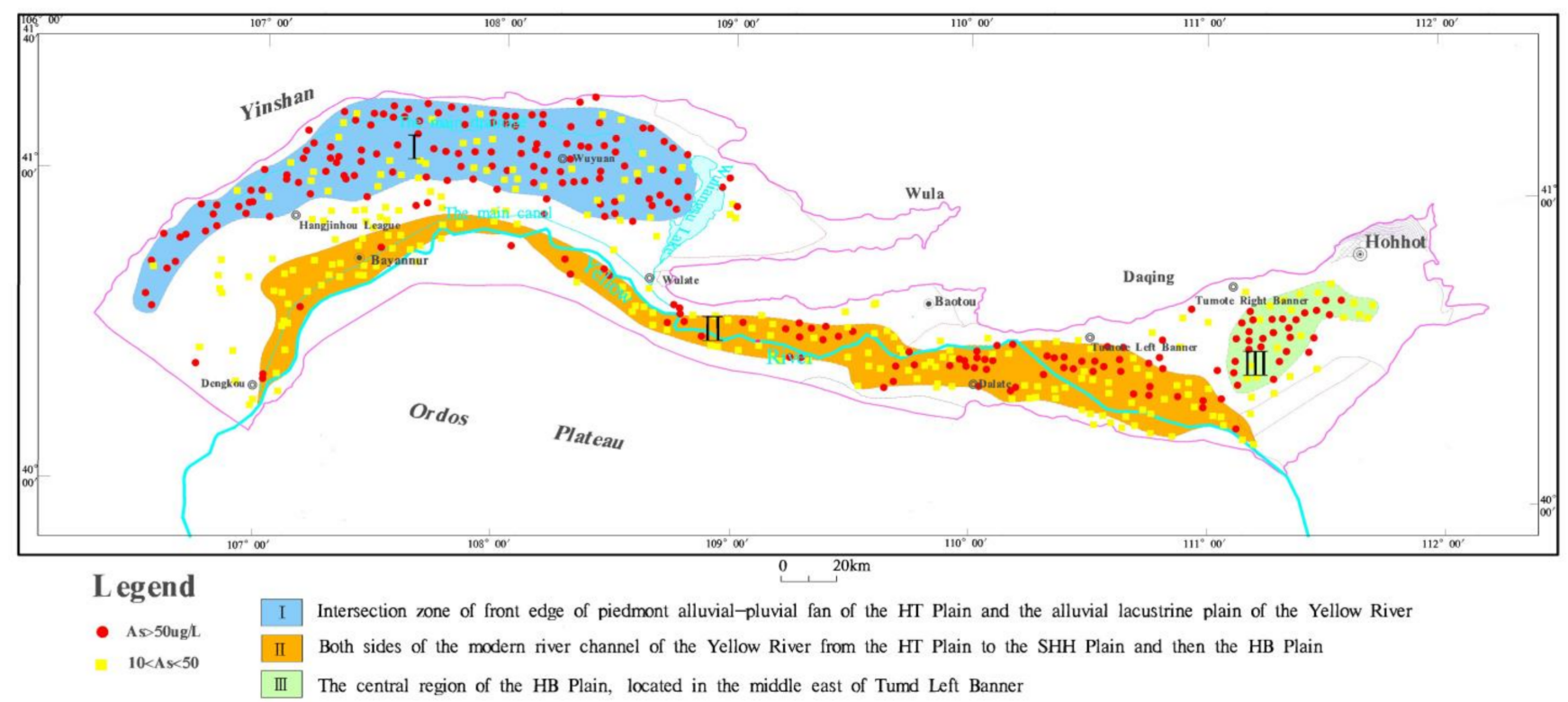

Figure 3. Contour map of high-arsenic shallow groundwater points and groundwater level elevation in Hetao Basin.

\subsection{Hydrochemical Characteristics of Shallow High As Groundwater}

In this part, 462 sets of shallow high-As groundwater samples are discussed, including 242 from the HT Plain, 29 from the SHH plain, 107 from the HB Plain, and 87 from the SBYR Plain. The groundwater was weakly alkaline, achieving a $\mathrm{pH}$ value of 7.15-9.26. The $\mathrm{pH}$ value of the HT plain approached that of the SBYR Plain, with levels of 7.15-9.26 and 7.37-9.25, respectively. The $\mathrm{pH}$ value of the SHH Plain approached that of the HB Plain, with levels of 7.44-8.65 and 7.26-8.76, respectively.

\subsubsection{Hydrochemical Types}

According to the Piper classification method [40], there were 13 hydrochemical types in the SHH Plain and 19 types in each of the other three hydrogeological units (Figure 4). However, they showed different hydrochemical characteristics. The major hydrochemical type of high-As groundwater in the HT Plain and the SHH Plain referred to the $\mathrm{HCO}_{3} \cdot \mathrm{SO}_{4} \cdot \mathrm{Cl}$ type, followed by the $\mathrm{HCO}_{3} \cdot \mathrm{Cl}$ type for anions, and mainly $\mathrm{Na} \cdot \mathrm{Mg} \cdot \mathrm{Ca}$ and $\mathrm{Na} \cdot \mathrm{Mg}$ for cations. The hydrochemical type of high-As groundwater in the HB Plain was largely the $\mathrm{HCO}_{3}$ type, followed by the $\mathrm{HCO}_{3} \cdot \mathrm{SO}_{4} \cdot \mathrm{Cl}$ type and $\mathrm{HCO}_{3} \cdot \mathrm{Cl}$ for anions, and mainly $\mathrm{Na}$ and $\mathrm{Na} \cdot \mathrm{Mg} \cdot \mathrm{Ca}$ for cations. The hydrochemical type of high-As groundwater in the SBYR Plain is mainly the $\mathrm{HCO}_{3}$ type, the $\mathrm{HCO}_{3} \cdot \mathrm{SO}_{4} \cdot \mathrm{Cl}$ type, the $\mathrm{HCO}_{3} \cdot \mathrm{SO}_{4}$ type, and the $\mathrm{HCO}_{3} \cdot \mathrm{Cl}$ type, all of which are approximately equally for anions, as well as $\mathrm{Na}, \mathrm{Na} \cdot \mathrm{Mg}$, and $\mathrm{Na} \cdot \mathrm{Mg} \cdot \mathrm{Ca}$ for cations. 

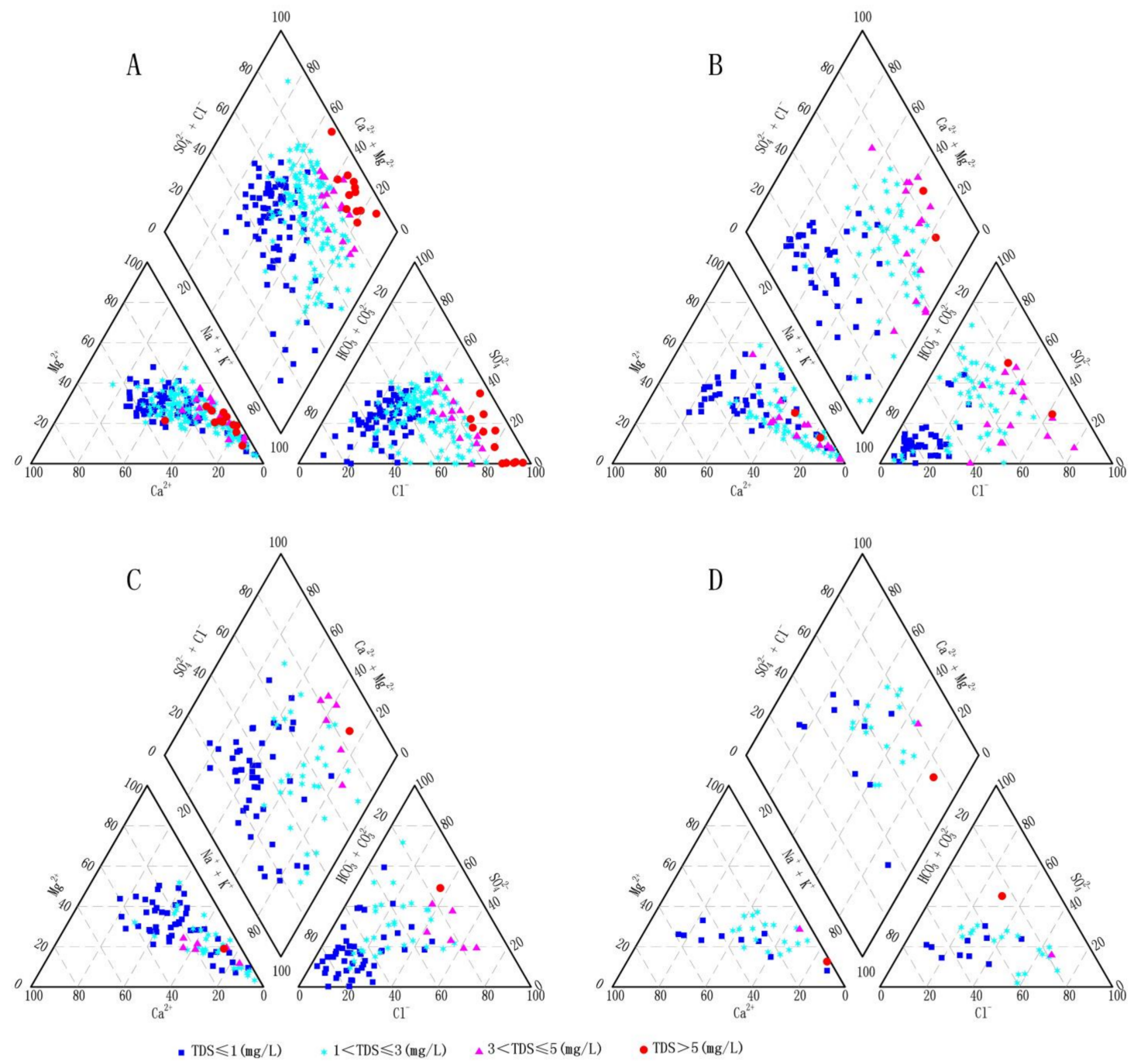

Figure 4. Piper diagram of high-arsenic shallow groundwater quality in four hydrogeological units. (A) HT Plain, (B) HB Plain, (C) SBYR Plain, and (D) SHH Plain.

\subsubsection{Main Ionic Components}

Given the statistical table of characteristic values of $\mathrm{As}, \mathrm{As}(\mathrm{III}), \mathrm{As}(\mathrm{V}), \mathrm{Fe}, \mathrm{Fe}^{2+}, \mathrm{Fe}^{3+}$, $\mathrm{HCO}_{3}{ }^{-}$and $\mathrm{SO}_{4}{ }^{2-}$ in shallow high-As groundwater in the Hetao Basin (Table 2), the average content of As in the shallow groundwater with high-As in the Hetao Basin reached $93.46 \mu \mathrm{g} / \mathrm{L}$, and the maximal content in the HT Plain was reported to be $116.93 \mu \mathrm{g} / \mathrm{L}$, nearly 2.5 times of that in the SBYR Plain; these values for the SHH Plain and the HB Plain were similar, reaching $76.20 \mu \mathrm{g} / \mathrm{L}$ and $80.65 \mu \mathrm{g} / \mathrm{L}$, respectively. In addition, As(III) was reported to be the major form of As, and the average concentration of As took up $85.2 \%$ of the total As. The minimal value was $76.1 \%$ in the SHH Plain, and the values in the other three hydrogeological units were nearly unchanged, ranging from $84.0 \%$ to $86.1 \%$, with the maximal value in the HT Plain. The ratios of $\mathrm{As}(\mathrm{III})$ to $\mathrm{As}(\mathrm{V})$ in the 4 plains are all very large, reaching 19.27 in the highest As area in the SHH Plain (Table 3), indicating that the groundwater in the entire Hetao Basin is basically in a reducing environment. Impacted by the toxicity of As(III) and such a high content of As(III) in the shallow high-As groundwater in the Hetao Basin, it is not difficult to understand that there are large-scale arsenic poisoning areas in the Hetao Basin and the safety of the drinking water of over one million people is affected $[28,29]$. 
Table 2. Statistical table of characteristic values of the main ions in high-As shallow groundwater in the Hetao Basin.

\begin{tabular}{|c|c|c|c|c|c|c|c|c|c|c|c|c|}
\hline \multirow{2}{*}{ Item } & \multicolumn{3}{|c|}{ As $(\mu \mathrm{g} / \mathrm{L})$} & \multicolumn{3}{|c|}{ As(III) $(\mu \mathrm{g} / \mathrm{L})$} & \multicolumn{3}{|c|}{$\operatorname{As}(V)(\mu g / L)$} & \multicolumn{3}{|c|}{$\mathrm{HCO}_{3}{ }^{-}(\mathrm{mg} / \mathrm{L})$} \\
\hline & Mean & Median & Max & Mean & Median & Max & Mean & Median & Max & Mean & Median & Max \\
\hline HT Plain & 116.93 & 58.21 & 916.70 & 100.69 & 50.99 & 719.40 & 16.24 & 6.95 & 224.60 & 521.34 & 480.70 & 1327.00 \\
\hline SHH Plain & 76.20 & 30.17 & 615.40 & 58.01 & 26.81 & 376.80 & 18.19 & 6.66 & 238.60 & 548.77 & 524.70 & 1347.00 \\
\hline HB Plain & 80.65 & 48.16 & 398.90 & 68.74 & 41.02 & 383.70 & 11.92 & 7.03 & 120.10 & 704.32 & 620.40 & 2123.00 \\
\hline SBYR Plain & 47.60 & 35.41 & 238.30 & 40.02 & 32.29 & 227.10 & 7.57 & 4.98 & 39.10 & 547.50 & 504.10 & 2220.00 \\
\hline Hetao Baisn & 93.46 & 49.64 & 916.70 & 79.67 & 41.02 & 719.40 & 13.80 & 6.52 & 238.60 & 570.25 & 505.00 & 2220.00 \\
\hline \multirow{2}{*}{ Item } & \multicolumn{3}{|c|}{$\mathrm{Fe}(\mathrm{mg} / \mathrm{L})$} & \multicolumn{3}{|c|}{$\mathrm{Fe}^{2+}(\mathrm{mg} / \mathrm{L})$} & \multicolumn{3}{|c|}{$\mathrm{Fe}^{3+}(\mathrm{mg} / \mathrm{L})$} & \multicolumn{3}{|c|}{$\mathrm{SO}_{4}{ }^{2-}(\mathrm{mg} / \mathrm{L})$} \\
\hline & Mean & Median & $\operatorname{Max}$ & Mean & Median & $\operatorname{Max}$ & Mean & Median & Max & Mean & Median & Max \\
\hline HT Plain & 2.63 & & 17.00 & 1.26 & 0.75 & & 1.37 & 0.53 & & & & 2494.00 \\
\hline SHH Plain & 5.84 & 2.40 & 40.00 & 2.59 & 1.20 & 30.00 & 3.25 & 0.80 & 24.00 & 291.90 & 227.90 & 2004.00 \\
\hline HB Plain & 2.60 & 1.32 & 25.00 & 1.17 & 0.48 & 17.00 & 1.43 & 0.52 & 22.00 & 360.65 & 263.20 & 2419.00 \\
\hline SBYR Plain & 2.33 & 0.88 & 34.00 & 1.02 & 0.28 & 17.00 & 1.32 & 0.52 & 17.00 & 264.77 & 172.20 & 2544.00 \\
\hline Hetao Baisn & 2.77 & 1.50 & 40.00 & 1.28 & 0.60 & 30.00 & 1.49 & 0.54 & 24.00 & 310.51 & 225.60 & 2544.00 \\
\hline
\end{tabular}

Table 3. As(III)/As(IV) ratios in shallow groundwater from Hetao Basin.

\begin{tabular}{|c|c|c|c|c|c|c|}
\hline \multirow{2}{*}{ Item } & \multicolumn{3}{|c|}{ As $<10 \mu \mathrm{g} / \mathrm{L}$} & \multicolumn{3}{|c|}{ As $\geq 10 \mu \mathrm{g} / \mathrm{L}$} \\
\hline & $\operatorname{As}(\mathrm{III})(\mu \mathrm{g} / \mathrm{L})$ & $\operatorname{As}(V)(\mu g / L)$ & $\operatorname{As}(\mathrm{III}) / \mathrm{As}(\mathrm{V})$ & $\operatorname{As}(\mathrm{III})(\mu \mathrm{g} / \mathrm{L})$ & $\operatorname{As}(V)(\mu g / L)$ & $\operatorname{As}(\mathrm{III}) / \mathrm{As}(\mathrm{V})$ \\
\hline HT Plain & 1.74 & 0.94 & 1.85 & 100.69 & 16.24 & 6.20 \\
\hline SHH Plain & 1.61 & 0.84 & 1.91 & 60.93 & 19.27 & 3.16 \\
\hline HB Plain & 1.2 & 0.56 & 2.14 & 71.89 & 12.71 & 5.66 \\
\hline SBYR plain & 2.12 & 0.97 & 2.19 & 39.35 & 7.38 & 5.33 \\
\hline
\end{tabular}

The content of total Fe in the Hetao Basin was higher, with an average concentration of $2.77 \mathrm{mg} / \mathrm{L}$, and the maximum value of $5.84 \mathrm{mg} / \mathrm{L}$ was identified in the SHH Plain. The average values of the other 3 hydrogeological units between were basically the same, at $2.33-2.63 \mathrm{mg} / \mathrm{L}$ (Figure 5). The average concentration of $\mathrm{Fe}^{2+}$ was $1.28 \mathrm{mg} / \mathrm{L}$, accounting for $46 \%$ of the total Fe. The average concentration of $\mathrm{Fe}^{3+}$ was $1.49 \mathrm{mg} / \mathrm{L}$, and the ratio of the average concentration of $\mathrm{Fe}^{2+}$ approached $1: 1$. The ratio of the average concentrations of $\mathrm{Fe}^{2+} / \mathrm{Fe}^{3+}$ in the 4 hydrogeological units approached 1:1 across the entire Hetao Basin.

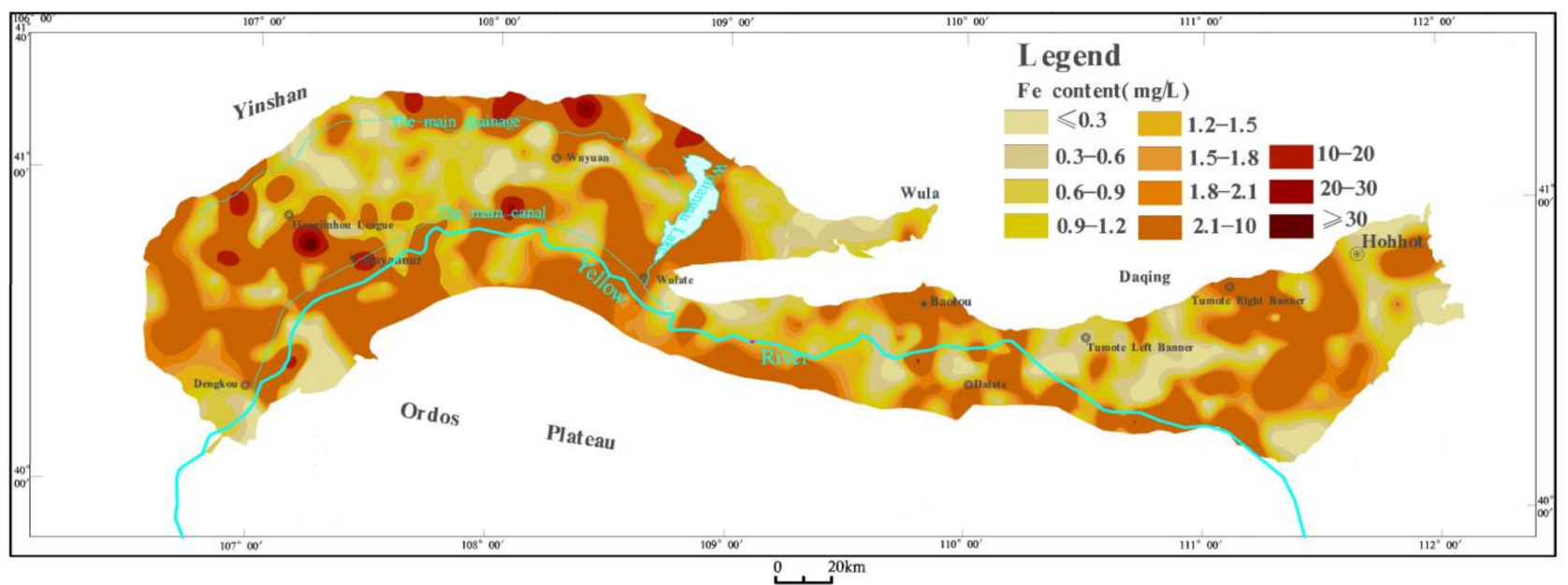

Figure 5. Contour map of total Fe content in Hetao Basin.

The average concentration of $\mathrm{SO}_{4}{ }^{2-}$ in the Hetao Basin reached $310 \mathrm{mg} / \mathrm{L}$, and the relative concentration was relatively low. The maximal value was $2455 \mathrm{mg} / \mathrm{L}$ in the SBYR Plain. 
The average concentration of $\mathrm{SO}_{4}{ }^{2-}$ in the 4 hydrogeological units was $264 \sim 360 \mathrm{mg} / \mathrm{L}$. Given the $\mathrm{SO}_{4}{ }^{2-}$ ion concentration partition of shallow high-As groundwater (Figure 6), the distribution area with concentrations of less than $100 \mathrm{mg} / \mathrm{L}$ was $4953 \mathrm{~km}^{2}$, and the distribution area with concentrations of 100 $200 \mathrm{mg} / \mathrm{L}$ was $4493 \mathrm{~km}^{2}$. There was almost no $\mathrm{SO}_{4}{ }^{2-}$ in the groundwater in the north of the HT Plain and in the eastern part of the HB Plain, which demonstrated the effect of desulfurization.

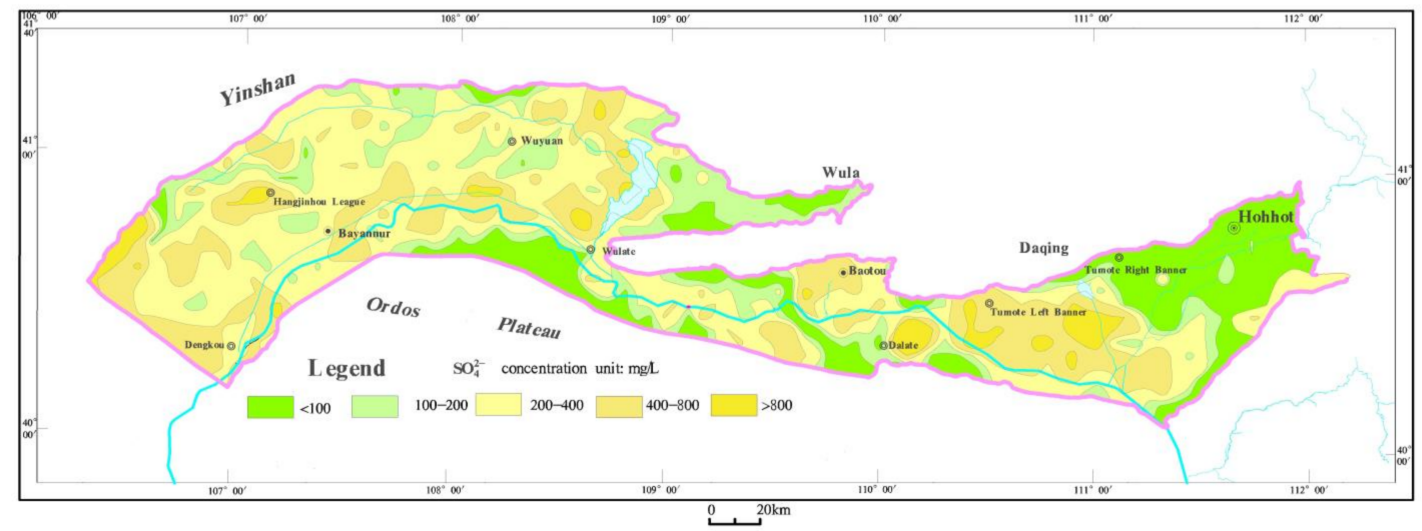

Figure 6. Zoning map of $\mathrm{SO}_{4}{ }^{2-}$ concentration in Hetao Basin.

The average concentration of $\mathrm{HCO}_{3}{ }^{-}$of the Hetao Basin was $570 \mathrm{mg} / \mathrm{L}$, and the relative concentration was relatively high. In four hydrogeological units, the average concentration of $\mathrm{HCO}_{3}{ }^{-}$of the $\mathrm{HB}$ Plain reached $704 \mathrm{mg} / \mathrm{L}$, and the values of the other 3 hydrogeological units were relatively close, at $521 \sim 547 \mathrm{mg} / \mathrm{L}$. The $\mathrm{HCO}_{3}{ }^{-}$concentration in the HB Plain tended to rise from the pre-piedmont recharge area to the central part of the plain (Figure 7). The highest concentration reached $2123 \mathrm{mg} / \mathrm{L}$, which demonstrated the effect of organic carbon oxidation.

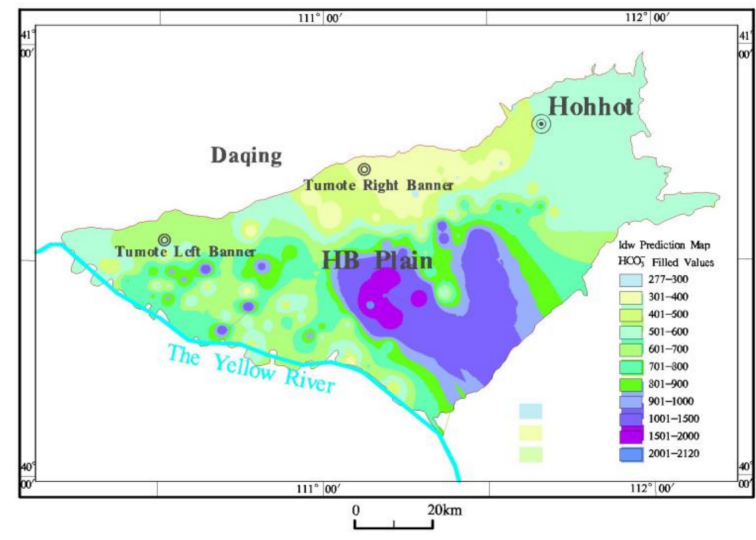

Figure 7. Contour map of $\mathrm{HB}$ Plain $\mathrm{HCO}_{3}{ }^{-}$concentration.

\section{Discussion}

\subsection{The Hydrogeochemical Process of As Mobilization in Aquifers}

Most of the potential sources of arsenic in the shallow groundwater of the Hetao Plain are believed to be from arsenic-bearing Quaternary strata derived from local aquifer sediments $[31,32,46]$. Under natural conditions, where the water-rock interaction is strong and the geochemical environment of certain aquifers is suitable for arsenic migration and accumulation, the aquifers often have higher arsenic concentrations. The migration of arsenic in the groundwater of the Hetao Basin occurs in a strong reducing environment with rich organic matter. The anaerobic environment where the surface lacustrine clay deposits is located is particularly conducive to the formation of As(III), causing As(III) 
to be the dominant valence state in the high-As groundwater in the study area. $\mathrm{pH}$ is an important factor affecting arsenic migration in aqueous systems. In the area of highAs groundwater in the Hetao Plain, the $\mathrm{pH}$ is also relatively high. Arsenic exists in the groundwater mainly in the form of two valence states as As(V) or As(III) anions, so it is more likely to be absorbed by positively charged substances in an aqueous medium, such as iron and manganese oxides, goethite, gibbsite and ferrihydrite. The increase of $\mathrm{pH}$ will reduce the adsorption of colloid and clay minerals to arsenate or arsenite in the form of anions and enhance their migration performance [47].

Numerous studies show that the finer the soil particles are, the greater amounts the arsenic adsorption are, and the higher the arsenic content is [48,49]. The silty-fine sand layer or the silty-fine sand interbeds with clay and silty clay are widely spread in the research area as identified by drilling data, and the organic matter content of the sediment is relatively high. Moreover, as the depth increases, the sediment particles become finer, and the arsenic content tends to increase [31]. The lacustrine silty clay and sandy clay in the sediment have a strong adsorption capacity for arsenic. When the arsenic element enters a depression with an alluvial or groundwater flow system, part of the arsenic is adsorbed by the clay and deposited directly, and part of the arsenic interacts with the ferric hydroxide colloid in the river or lake water to form insoluble precipitates. At the same time, the study area is rich in $\mathrm{Fe}^{2+}$ and $\mathrm{Fe}^{3+}$, and iron ions have a strong ability to fix arsenic. Once groundwater rich in iron and arsenic ions flow to the central area of the plain, the slow flow of groundwater, caused by the low hydraulic gradient, poor aquifer permeability and small recharge, will limit aquifer flushing, solute (As) transport and its removal from the system. In areas with slow groundwater movement, aqueous As concentrations are very sensitive to releases of small amounts of arsenic from the various hydrogeochemical processes described above. These reasons also explain the high-As distribution in the three main regions.

\subsection{Correlation Analysis between Arsenic and Main Oxidation-Reducing Ions}

Pearson correlation analysis was applied to reveal the relationship between arsenic and the main oxidation-reducing ions in this study [50-54]. As revealed by the results of the Pearson correlation analysis of arsenic with major ions (e.g., As, $\mathrm{Fe}, \mathrm{Fe}^{2+}, \mathrm{Fe}^{3+}, \mathrm{HCO}_{3}{ }^{-}$, $\mathrm{SO}_{4}{ }^{2-}, \mathrm{NO}_{2}{ }^{-}$and $\left.\mathrm{NO}_{3}{ }^{-}\right)$for all shallow groundwater samples $(n=974)$ (significance level at $p<0.01$, Table 4), no significant correlation was reported between arsenic and the ions, and the correlation coefficient was primarily less than 0.4 . As indicated by the results of the separate correlation analysis regarding the groundwater samples of the four hydrogeological units (Tables 5-8), an insignificant correlation was reported between arsenic and other ions; only in the SHH Plain was a correlation coefficient of 0.6 found between arsenic and $\mathrm{Fe}$, and the correlation coefficient between arsenic and $\mathrm{NO}_{2}{ }^{-}$was 0.5 , which was more significant. No significant correlation was identified between the arsenic and the iron contents in the groundwater, probably due to the formation of insoluble iron sulfides by $\mathrm{Fe}^{2+}$ from the reduction of iron oxides and by $\mathrm{S}^{2-}$ from the reduction of $\mathrm{SO}_{4}{ }^{2-}$. Iron sulfides have been extensively distributed in many high-As aquifers worldwide [55]. No significant correlation was identified between arsenic and $\mathrm{HCO}_{3}{ }^{-}$concentration in the groundwater, whereas high-As groundwater samples generally contained $\mathrm{HCO}_{3}{ }^{-}$in high concentrations. In this study area, the average concentration of $\mathrm{HCO}_{3}{ }^{-}$was relatively high, up to $570 \mathrm{mg} / \mathrm{L}$, which might also be related to the process of microbial activity. Microorganisms can reduce iron's release of arsenic and oxidize the organic matter in the aquifer to produce a large amount of $\mathrm{HCO}_{3}{ }^{-}$. In addition, it might be related to high concentrations of $\mathrm{HCO}_{3}{ }^{-}$and the competitive adsorption of arsenate and arsenite on the surface of iron oxide. 
Table 4. Pearson correlation analysis between As and the main redox ions in the Hetao Plain $(n=974)$.

\begin{tabular}{|c|c|c|c|c|c|c|c|c|c|c|}
\hline & As & $\mathrm{Fe}$ & As(III) & $\operatorname{As}(\mathrm{V})$ & $\mathrm{Fe}^{2+}$ & $\mathrm{Fe}^{3+}$ & $\mathrm{HCO}_{3}{ }^{-}$ & $\mathrm{NO}_{2}{ }^{-}$ & $\mathrm{NO}_{3}{ }^{-}$ & $\mathrm{SO}_{4}{ }^{2-}$ \\
\hline As & 1 & $0.242 * *$ & $0.992 * *$ & $0.797^{* *}$ & $0.170^{* *}$ & $0.231^{* *}$ & $0.177^{* *}$ & -0.007 & $-0.093^{* *}$ & -0.044 \\
\hline $\mathrm{Fe}$ & $0.242^{* *}$ & 1 & $0.213^{* *}$ & $0.315^{* *}$ & $0.812^{* *}$ & $0.843^{* *}$ & 0.139 ** & -0.013 & $-0.080^{*}$ & $0.171^{* *}$ \\
\hline As(III) & $0.992^{* *}$ & $0.213^{* *}$ & 1 & $0.712^{* *}$ & $0.167^{* *}$ & $0.188^{* *}$ & $0.171^{* *}$ & -0.010 & $-0.095^{* *}$ & -0.050 \\
\hline $\mathrm{As}(\mathrm{V})$ & $0.797^{* *}$ & $0.315^{* *}$ & $0.712 * *$ & 1 & $0.140^{* *}$ & $0.375^{* *}$ & $0.159^{* *}$ & 0.007 & -0.062 & -0.004 \\
\hline $\mathrm{Fe}^{* *}$ & $0.170^{* *}$ & $0.812^{* *}$ & $0.167^{* *}$ & $0.140^{* *}$ & 1 & $0.378^{* *}$ & 0.054 & -0.011 & $-0.093^{* *}$ & $0.105^{* *}$ \\
\hline $\mathrm{Fe}^{* *}$ & $0.231^{* *}$ & $0.843^{* *}$ & $0.188^{* *}$ & $0.375^{* *}$ & $0.378^{* *}$ & 1 & $0.175^{* *}$ & -0.010 & -0.042 & $0.178^{* * *}$ \\
\hline $\mathrm{HCO}_{3}$ * & $0.177^{* *}$ & $0.139 * *$ & $0.171^{* *}$ & $0.159 * *$ & 0.054 & $0.175^{* *}$ & 1 & 0.068 * & $0.081 *$ & 0.382 ** \\
\hline $\mathrm{NO}_{2}$ * & -0.007 & -0.013 & -0.010 & 0.007 & -0.011 & -0.010 & 0.068 * & 1 & $0.270 * *$ & 0.011 \\
\hline $\mathrm{NO}_{3}$ * & $-0.093^{* *}$ & $-0.080 *$ & $-0.095 * *$ & -0.062 & $-0.093^{* *}$ & -0.042 & 0.081 * & $0.270 * *$ & 1 & $0.155^{* *}$ \\
\hline $\mathrm{SO}_{4}^{* *}$ & -0.044 & $0.171^{* *}$ & -0.050 & -0.004 & $0.105^{* *}$ & $0.178^{* *}$ & $0.382^{* *}$ & 0.011 & $0.155^{* *}$ & 1 \\
\hline
\end{tabular}

** Significantly correlated at the level of 0.01 (bilateral); * Significantly correlated at the level of 0.05 (bilateral).

Table 5. Pearson correlation analysis between As and the main redox ions in the Houtao Plain $(n=190)$.

\begin{tabular}{|c|c|c|c|c|c|c|c|c|c|c|}
\hline & As & $\mathrm{Fe}$ & As(III) & $\operatorname{As}(\mathrm{V})$ & $\mathrm{Fe}^{* *}$ & $\mathrm{Fe}^{* *}$ & $\mathrm{HCO}_{3}$ * & $\mathrm{NO}_{2} *$ & $\mathrm{NO}_{3} *$ & $\mathrm{SO}_{4} * *$ \\
\hline As & 1 & $0.182^{* *}$ & $0.993 * *$ & $0.797^{* *}$ & $0.115^{*}$ & $0.181^{* *}$ & $0.212^{* *}$ & $0.137^{* *}$ & 0.056 & $-0.124^{* *}$ \\
\hline $\mathrm{Fe}$ & $0.182 * *$ & 1 & $0.161^{* *}$ & $0.243^{* *}$ & $0.821^{* *}$ & $0.796^{* *}$ & $0.166^{* *}$ & 0.025 & -0.020 & $0.240 * *$ \\
\hline As(III) & $0.993^{* *}$ & $0.161^{* *}$ & 1 & $0.720 * *$ & $0.121^{*}$ & $0.141^{* *}$ & $0.210^{* *}$ & $0.144^{* *}$ & 0.057 & $-0.137^{* *}$ \\
\hline $\mathrm{As}(\mathrm{V})$ & $0.797^{* *}$ & $0.243^{* *}$ & $0.720 * *$ & 1 & 0.057 & $0.345^{* *}$ & $0.174^{* *}$ & 0.066 & 0.040 & -0.027 \\
\hline $\mathrm{Fe}^{* *}$ & 0.115 * & $0.821^{* *}$ & $0.121 *$ & 0.057 & 1 & $0.308^{* *}$ & 0.030 & 0.045 & -0.024 & $0.191^{* *}$ \\
\hline $\mathrm{Fe}^{* *}$ & $0.181^{* *}$ & $0.796^{* *}$ & $0.141^{* *}$ & $0.345^{* *}$ & $0.308^{* *}$ & 1 & $0.246^{* *}$ & -0.007 & -0.008 & $0.198^{* *}$ \\
\hline $\mathrm{HCO}_{3}$ * & $0.212^{* *}$ & $0.166^{* *}$ & $0.210 * *$ & $0.174^{* *}$ & 0.030 & $0.246^{* *}$ & 1 & $0.125^{* *}$ & -0.041 & $0.283^{* *}$ \\
\hline $\mathrm{NO}_{2} *$ & $0.137^{* *}$ & 0.025 & $0.144^{* *}$ & 0.066 & 0.045 & -0.007 & $0.125^{* *}$ & 1 & 0.042 & 0.092 \\
\hline $\mathrm{NO}_{3}$ * & 0.056 & -0.020 & 0.057 & 0.040 & -0.024 & -0.008 & -0.041 & 0.042 & 1 & $0.189 * *$ \\
\hline $\mathrm{SO}_{4} * *$ & $-0.124^{* *}$ & $0.240^{* *}$ & $-0.137^{* *}$ & -0.027 & $0.191^{* *}$ & $0.198^{* *}$ & $0.283^{* *}$ & 0.092 & $0.189^{* *}$ & 1 \\
\hline
\end{tabular}

** Significantly correlated at the level of 0.01 (bilateral); * Significantly correlated at the level of 0.05 (bilateral).

Table 6. Pearson correlation analysis between As and the main redox ions in the Sanhuhe Plain $(n=190)$.

\begin{tabular}{|c|c|c|c|c|c|c|c|c|c|c|}
\hline & As & Fe & As(III) & $\operatorname{As}(\mathrm{V})$ & $\mathrm{Fe}^{* *}$ & $\mathrm{Fe}^{* *}$ & $\mathrm{HCO}_{3}$ * & $\mathrm{NO}_{2} *$ & $\mathrm{NO}_{3}{ }^{*}$ & $\mathrm{SO}_{4} * *$ \\
\hline As & 1 & $0.574^{* *}$ & $0.988^{* *}$ & $0.958^{* *}$ & $0.348^{* *}$ & $0.629^{* *}$ & $0.368^{* *}$ & $0.476^{* *}$ & -0.167 & -0.043 \\
\hline $\mathrm{Fe}$ & $0.574^{* *}$ & 1 & $0.560 * *$ & $0.563 * *$ & $0.826^{* *}$ & $0.849^{* *}$ & 0.117 & 0.174 & -0.218 & -0.073 \\
\hline As(III) & $0.988^{* *}$ & $0.560 * *$ & 1 & $0.901^{* *}$ & $0.359 * *$ & $0.597^{* *}$ & $0.378^{* *}$ & $0.495^{* *}$ & -0.203 & -0.040 \\
\hline $\mathrm{As}(\mathrm{V})$ & $0.958^{* *}$ & $0.563^{* *}$ & $0.901^{* *}$ & 1 & 0.305 * & $0.648^{* *}$ & $0.327^{*}$ & $0.411^{* *}$ & -0.091 & -0.044 \\
\hline $\mathrm{Fe}^{* *}$ & $0.348^{* *}$ & $0.826^{* *}$ & $0.359 * *$ & 0.305 * & 1 & $0.433^{* *}$ & 0.096 & 0.131 & -0.182 & -0.062 \\
\hline $\mathrm{Fe}^{* *}$ & $0.629 * *$ & $0.849^{* *}$ & $0.597 * *$ & $0.648^{* *}$ & $0.433^{* *}$ & 1 & 0.131 & 0.180 & -0.170 & -0.040 \\
\hline $\mathrm{HCO}_{3}$ * & $0.368^{* *}$ & 0.117 & $0.378^{* *}$ & 0.327 * & 0.096 & 0.131 & 1 & $0.489 * *$ & 0.020 & $0.687^{* *}$ \\
\hline $\mathrm{NO}_{2}$ * & $0.476^{* *}$ & 0.174 & $0.495^{* *}$ & $0.411^{* *}$ & 0.131 & 0.180 & $0.489^{* *}$ & 1 & -0.141 & 0.210 \\
\hline $\mathrm{NO}_{3}$ * & -0.167 & -0.218 & -0.203 & -0.091 & -0.182 & -0.170 & 0.020 & -0.141 & 1 & $0.406^{* *}$ \\
\hline $\mathrm{SO}_{4} * *$ & -0.043 & -0.073 & -0.040 & -0.044 & -0.062 & -0.040 & $0.687^{* *}$ & 0.210 & $0.406^{* *}$ & 1 \\
\hline
\end{tabular}


Table 7. Pearson correlation analysis between As and the main redox ions in the Hubao Plain $(n=278)$.

\begin{tabular}{|c|c|c|c|c|c|c|c|c|c|c|}
\hline & As & $\mathrm{Fe}$ & As(III) & $\operatorname{As}(\mathrm{V})$ & $\mathrm{Fe}^{* *}$ & $\mathrm{Fe}^{* *}$ & $\mathrm{HCO}_{3}$ * & $\mathrm{NO}_{2}$ * & $\mathrm{NO}_{3}$ * & $\mathrm{SO}_{4} * *$ \\
\hline As & 1 & $0.288^{* *}$ & 0.993 ** & $0.810 * *$ & $0.237^{* *}$ & $0.229 * *$ & $0.217^{* *}$ & -0.045 & $-0.175^{* *}$ & 0.020 \\
\hline $\mathrm{Fe}$ & $0.288^{* *}$ & 1 & $0.285^{* *}$ & $0.238^{* *}$ & $0.704^{* *}$ & $0.876^{* *}$ & $0.182^{* *}$ & -0.044 & -0.087 & $0.277^{* *}$ \\
\hline As(III) & $0.993^{* *}$ & $0.285^{* *}$ & 1 & $0.733^{* *}$ & $0.242 * *$ & $0.221^{* *}$ & $0.208^{* *}$ & -0.049 & $-0.181^{* *}$ & 0.018 \\
\hline $\mathrm{As}(\mathrm{V})$ & $0.810^{* *}$ & $0.238^{* *}$ & $0.733 * *$ & 1 & $0.157^{* *}$ & $0.216^{* *}$ & $0.214^{* *}$ & -0.018 & -0.107 & 0.027 \\
\hline $\mathrm{Fe}^{* *}$ & $0.237^{* *}$ & $0.704^{* *}$ & $0.242^{* *}$ & $0.157^{* *}$ & 1 & $0.275^{* *}$ & $0.119 *$ & -0.043 & $-0.145^{*}$ & $0.156^{* *}$ \\
\hline $\mathrm{Fe}^{* *}$ & $0.229 * *$ & $0.876^{* *}$ & $0.221^{* *}$ & $0.216^{* *}$ & $0.275^{* *}$ & 1 & $0.167^{* *}$ & -0.030 & -0.019 & $0.269 * *$ \\
\hline $\mathrm{HCO}_{3}$ * & $0.217^{* *}$ & $0.182^{* *}$ & $0.208^{* *}$ & $0.214^{* *}$ & $0.119 *$ & $0.167^{* *}$ & 1 & 0.056 & 0.101 & $0.417^{* *}$ \\
\hline $\mathrm{NO}_{2}{ }^{*}$ & -0.045 & -0.044 & -0.049 & -0.018 & -0.043 & -0.030 & 0.056 & 1 & $0.298^{* *}$ & 0.013 \\
\hline $\mathrm{NO}_{3} *$ & $-0.175^{* *}$ & -0.087 & $-0.181^{* *}$ & -0.107 & $-0.145^{*}$ & -0.019 & 0.101 & $0.298^{* *}$ & 1 & $0.278^{* *}$ \\
\hline $\mathrm{SO}_{4} * *$ & 0.020 & $0.277^{* *}$ & 0.018 & 0.027 & $0.156^{* *}$ & $0.269^{* *}$ & $0.417^{* *}$ & 0.013 & $0.278^{* *}$ & 1 \\
\hline
\end{tabular}

Table 8. Pearson correlation analysis between As and the main redox ions in the Southern Plain of the Yellow River $(n=190)$.

\begin{tabular}{|c|c|c|c|c|c|c|c|c|c|c|}
\hline & As & $\mathrm{Fe}$ & As(III) & $\operatorname{As}(\mathrm{V})$ & $\mathrm{Fe}^{* *}$ & $\mathrm{Fe}^{* *}$ & $\mathrm{HCO}_{3} *$ & $\mathrm{NO}_{2} *$ & $\mathrm{NO}_{3} *$ & $\mathrm{SO}_{4} * *$ \\
\hline As & 1 & $0.320 * *$ & 0.993 ** & $0.823^{* *}$ & $0.315^{* *}$ & $0.283^{* *}$ & $0.231^{* *}$ & -0.074 & $-0.175^{*}$ & 0.006 \\
\hline $\mathrm{Fe}$ & $0.320 * *$ & 1 & $0.303^{* *}$ & $0.334^{* *}$ & $0.903^{* *}$ & $0.945^{* *}$ & 0.186 * & -0.046 & -0.096 & $0.195^{* *}$ \\
\hline As(III) & 0.993 ** & 0.303 ** & 1 & 0.750 ** & $0.321^{* *}$ & $0.251^{* *}$ & $0.227^{* *}$ & -0.073 & -0.176 * & -0.004 \\
\hline $\mathrm{As}(\mathrm{V})$ & $0.823^{* *}$ & $0.334^{* *}$ & $0.750 * *$ & 1 & $0.223^{* *}$ & $0.376^{* *}$ & $0.201^{* *}$ & -0.063 & -0.133 & 0.050 \\
\hline $\mathrm{Fe}^{* *}$ & $0.315^{* *}$ & $0.903^{* *}$ & $0.321 * *$ & $0.223^{* *}$ & 1 & $0.713^{* *}$ & 0.118 & -0.034 & -0.118 & 0.099 \\
\hline $\mathrm{Fe}^{* *}$ & $0.283^{* *}$ & $0.945^{* *}$ & $0.251 * *$ & $0.376^{* *}$ & $0.713^{* *}$ & 1 & $0.214^{* *}$ & -0.049 & -0.067 & $0.243^{* *}$ \\
\hline $\mathrm{HCO}_{3}$ * & $0.231^{* *}$ & 0.186 * & $0.227^{* *}$ & $0.201^{* *}$ & 0.118 & $0.214^{* *}$ & 1 & 0.043 & -0.011 & $0.491^{* *}$ \\
\hline $\mathrm{NO}_{2} *$ & -0.074 & -0.046 & -0.073 & -0.063 & -0.034 & -0.049 & 0.043 & 1 & 0.075 & 0.036 \\
\hline $\mathrm{NO}_{3}$ * & $-0.175^{*}$ & -0.096 & $-0.176^{*}$ & -0.133 & -0.118 & -0.067 & -0.011 & 0.075 & 1 & 0.072 \\
\hline $\mathrm{SO}_{4} * *$ & 0.006 & $0.195^{* *}$ & -0.004 & 0.050 & 0.099 & $0.243^{* *}$ & $0.491^{* *}$ & 0.036 & 0.072 & 1 \\
\hline
\end{tabular}

** Significantly correlated at the level of 0.01 (bilateral); * Significantly correlated at the level of 0.05 (bilateral).

\subsection{Correlation between Formation of High As Groundwater and Geological Environment}

Large-scale high-As groundwater deposits tend to be found in two types of environments, i.e., inland or closed basins in arid or semi-arid regions and aquifers derived from alluvium under strong reducing conditions [23]. Both environments tend to contain geologically young sediments and to be in flat, low-lying areas where groundwater flow is sluggish. The Hetao Basin, which is located in the west of Inner Mongolia, pertains to the typical temperate continental arid and semi-arid climate. The annual precipitation is $245.5 \mathrm{~mm}$, and the average water evaporation is $2100 \mathrm{~mm}[38,39]$, which is 9 times the average rainfall.

The Hetao Basin is a Mesozoic-Cenozoic rifted basin formed in the late Jurassic, located between the Yinshan uplift and the Ordos platform. The tectonic movement of the Hetao Basin is very active, and tectonic faults have developed since the Cenozoic. The tectonic systems are dominated by high-angle normal faults and fault-bending belts. The deep east-west fault formed in the piedmont of Yinshan Mountain made the Ordos block continue to squeeze to the northwest, and the Hetao Basin between these two began to sink into depression. Since the Cenozoic, the Ordos block has been pushed from the northwest direction, and the squeeze turned into a southeastward pulling, which caused the Hetao Basin to sink significantly, forming a tectonic pattern termed as "three sags and two uplifts", in which the basin and mountains intersect each other and the depression and uplift are adjacent to each other (Figure 1). The fault depressions are favorable places for arsenic enrichment. Strong evaporation and weathering accelerate the decomposition rate and biogeochemical cycle of minerals in the bedrock weathering zone and promote the migration and enrichment of arsenic in water. Moreover, in the depression, the underground flow is stagnant, forming a structural water storage area and 
a gathering place for various elements. The enclosed tectonic conditions and long-term inheritance and subsidence of the Hetao Basin has resulted in the formation of fine-grained clastic sediments dominated by inland lacustrine facies. The thickness of the Quaternary sedimentary reached 200-1500 m. Center areas of the low-lying lake basins located in piedmonts contain fine-grained sediments and high amounts of organic matter, and these reducing environments create favorable conditions for the release of arsenic from the sediments and the accumulation of arsenic in the water. The coverage of fine-grained sediments isolates the air exchange of oxygen between the aquifer and the surface, forming a closed reducing environment, prompting the release and migration of arsenic.

Mineral-water interactions can make arsenic enter groundwater from the sediment adsorption phase. However, arsenic in groundwater must accumulate to a certain concentration before it can form high-As groundwater [23]. Obviously, in the middle of a low-lying basin, especially in areas with a large thickness of lacustrine sediments, slow groundwater runoff and evaporation as the main form of discharge, it is particularly easy to develop high-As groundwater [56]. There are three relatively concentrated areas of high-As groundwater points in the Hetao Basin, located in the discharge area of groundwater according to the contours of the groundwater table (Figure 8), where there is a small groundwater depth and a hydraulic gradient of less than $0.8 \%$, and the groundwater flow is slow [55]. As the mentioned three areas are situated in the pluvial and alluvial-lacustrine interlace lowland and interfluvial lowland, characterized by poor water flow, strong evaporation and widespread saline-alkali land, the sediments are saturated in long periods. These factors enhance the release of arsenic from sediments into the water, causing its high concentration.

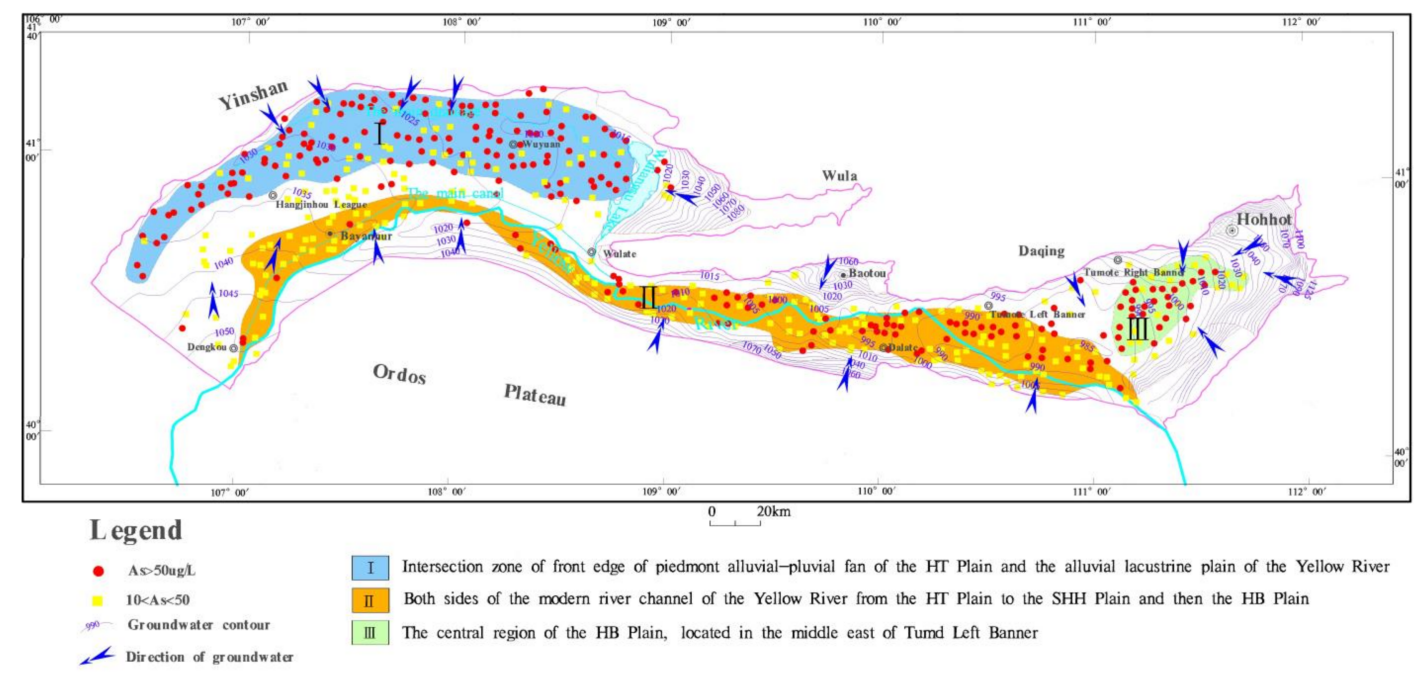

Figure 8. Contour map of groundwater table in Hetao Basin.

Due to the low rainfall and large evaporation, agricultural production in the Hetao Basin is primarily supported by the water from the Yellow River, and the introduction of considerable Yellow River water up-regulates the groundwater water level and forms a large area of soil salinization. Furthermore, the rising water level makes air unable to enter the reduction environment formed by the stratum. Besides, the $\mathrm{pH}$ value of the surface water in the arid and semi-arid climate environment is basically high, thereby creating favorable conditions for the dissolution of arsenic from the stratum.

\section{Conclusions}

Arsenic has been extensively distributed in the shallow groundwater of the Hetao Basin, and high-As groundwater was identified in the four hydrogeological units. In particular, the average concentration of arsenic in the shallow groundwater in the Hetao Basin reached $45.58 \mu \mathrm{g} / \mathrm{L}$. The spatial distribution of arsenic content in the shallow groundwater 
was significantly uneven in the whole basin, and the variation coefficient ranged from 2.07 to $1.57-2.18$, with high variability.

All high-As groundwater in the HT Basin was weakly alkaline, achieving a $\mathrm{pH}$ value of 7.15-9.26. As(III) was found to be the major form of As, and the average concentration of As took up $85 \%$ of the total As. The content of total Fe was higher, with a concentration of $2.77 \mathrm{mg} / \mathrm{L}$ on average, and the average concentration of $\mathrm{Fe}^{2+}$ took up $46 \%$ of the total $\mathrm{Fe}$. The average concentration of $\mathrm{SO}_{4}{ }^{2-}$ was $310 \mathrm{mg}$, and the relative concentration was lower. It is noteworthy that there was nearly no $\mathrm{SO}_{4}{ }^{2-}$ in the groundwater in the north of the HT Plain and in the eastern part of the HB Plain, which demonstrated the effect of desulfurization. The concentration of $\mathrm{HCO}_{3}{ }^{-}$was $460 \mathrm{mg} / \mathrm{L}$ on average, and the relative concentration was higher. The $\mathrm{HCO}_{3}{ }^{-}$concentration in the $\mathrm{HB}$ Plain tended to rise from the pre-piedmont recharge area to the central part of the plain, and the maximal concentration was $2123 \mathrm{mg} / \mathrm{L}$, which demonstrated the effect of organic carbon oxidation.

There were three concentrated areas with high-As groundwater in the Hetao Basin where the arsenic contents of groundwater were more than $50 \mu \mathrm{g} / \mathrm{L}$. According to the analysis of hydrogeological conditions, three concentrated distribution areas with high-As groundwater were all in the discharge areas of groundwater with a shallow groundwater level, a water gradient of less than $0.8 \%$ and slow groundwater flow.

The distribution of high-As groundwater was found to be dependent on specific geological and geographical backgrounds. The special sedimentary environment evolution of the Hetao Basin lays the prerequisite for creating high-As groundwater, and the groundwater runoff condition and hydrogeochemical process of the basin can control the formation of high-As groundwater. The high $\mathrm{pH}$ and organic-rich reducing environment in the Hetao Basin, the dissolution, reduction, and precipitation of various minerals and the mutual transformation of different forms of arsenic contribute to the origin of the high-arsenic groundwater. The long-term lacustrine-dominated paleogeographic environment and closed tectonic conditions, slow refreshment and stagnant groundwater, arid-semi-arid climatic conditions, as well as sediments with high arsenic content and regional arsenic-rich environments constitute the feasible conditions for high-arsenic groundwater.

Author Contributions: L.L. and Z.C. designed the idea and structure of the article, W.X. analyzed the data, P.W. drew the graph, and Z.C., L.L. and C.L. wrote the paper. All authors have read and agreed to the published version of the manuscript.

Funding: This research was funded by the National Natural Science Foundation of China (No.41672241) and the Geological Survey Project of China Geological Survey (NO.DD20190433).

Institutional Review Board Statement: Not applicable.

Informed Consent Statement: Not applicable.

Data Availability Statement: Not applicable.

Conflicts of Interest: The authors declare no conflict of interest.

\section{References}

1. He, X.; Li, P.; Ji, Y.; Wang, Y.; Su, Z.; Elumalai, V. Groundwater arsenic and fluoride and associated arsenicosis and fluorosis in China: Occurrence, distribution and management. Expo. Health 2020, 12, 355-368. [CrossRef]

2. He, X.; Li, P.; Wu, J.; Wei, M.; Ren, X.; Wang, D. Poor groundwater quality and high potential health risks in the Datong Basin, northern China: Research from published data. Environ. Geochem. Health 2021, 43, 791-812. [CrossRef] [PubMed]

3. Nsabimana, A.; Li, P.; He, S.; He, X.; Alam, S.M.K.; Fida, M. Health risk of the shallow groundwater and its suitability for drinking purpose in Tongchuan, China. Water 2021, 13, 3256. [CrossRef]

4. Wang, Y.; Li, P. Appraisal of shallow groundwater quality with human health risk assessment in different seasons in rural areas of the Guanzhong Plain (China). Environ. Res. 2022, 207, 112210. [CrossRef]

5. Zhang, Q.; Li, P.; Lyu, Q.; Ren, X.; He, S. Groundwater contamination risk assessment using a modified DRATICL model and pollution loading: A case study in the Guanzhong Basin of China. Chemosphere 2022, 291, 132695. [CrossRef] [PubMed]

6. Li, Y.; Li, P.; Cui, X.; He, S. Groundwater quality, health risk, and major influencing factors in the lower Beiluo River watershed of Northwest China. Hum. Ecol. Risk Assess. 2021, 27, 1987-2013. [CrossRef] 
7. Wu, J.; Zhou, H.; He, S.; Zhang, Y. Comprehensive understanding of groundwater quality for domestic and agricultural purposes in terms of health risks in a coal mine area of the Ordos basin, north of the Chinese Loess Plateau. Environ. Earth Sci. 2019, 78, 446. [CrossRef]

8. Wu, J.; Zhang, Y.; Zhou, H. Groundwater chemistry and groundwater quality index incorporating health risk weighting in Dingbian County, Ordos basin of Northwest China. Geochemistry 2020, 80, 125607. [CrossRef]

9. Hu, G.; Mian, H.R.; Dyck, R.; Mohseni, M.; Jasim, S.; Hewage, K.; Sadiq, R. Drinking water treatments for arsenic and manganese removal and health risk assessment in white rock, Canada. Expo. Health 2020, 12, 793-807. [CrossRef]

10. Wei, M.; Wu, J.; Li, W.; Zhang, Q.; Su, F.; Wang, Y. Groundwater geochemistry and its impacts on groundwater arsenic enrichment, variation, and health risks in Yongning County, Yinchuan Plain of Northwest China. Expo. Health 2021, 1-20. [CrossRef]

11. Alam, M.O.; Shaikh, W.A.; Chakraborty, S.; Avishek, K.; Bhattacharya, T. Groundwater arsenic contamination and potential health risk assessment of gangetic plains of Jharkhand, India. Expo. Health 2016, 8, 125-142. [CrossRef]

12. Li, Y.; Ma, L.; Abuduwaili, J.; Li, Y.; Uulu, S.A. Spatiotemporal distributions of fluoride and arsenic in rivers with the role of mining industry and related human health risk assessments in Kyrgyzstan. Expo. Health 2021, 1-14. [CrossRef]

13. Fano, D.; Vásquez-Velásquez, C.; Aguilar, J.; Gribble, M.O.; Wickliffe, J.K.; Lichtveld, M.Y.; Steenland, K.; Gonzales, G.F. Arsenic concentrations in household drinking water: A cross-sectional survey of pregnant women in Tacna, Peru, 2019. Expo. Health 2020, 12, 555-560. [CrossRef] [PubMed]

14. Sathe, S.S.; Mahanta, C.; Subbiah, S. Hydrogeochemical evaluation of intermittent alluvial aquifers controlling arsenic and fluoride contamination and corresponding health risk assessment. Expo. Health 2021, 13, 661-680. [CrossRef]

15. Owusu, C.; Silverman, G.S.; Vinson, D.S.; Bobyarchick, A.; Paul, R.; Delmelle, E. A spatial autologistic model to predict the presence of arsenic in private wells across Gaston County, North Carolina using geology, well depth, and pH. Expo. Health 2021, 13, 195-206. [CrossRef]

16. Joardar, M.; Das, A.; Mridha, D.; De, A.; Chowdhury, N.R.; Roychowdhury, T. Evaluation of acute and chronic arsenic exposure on school children from exposed and apparently control areas of West Bengal, India. Expo. Health 2021, 13, 33-50. [CrossRef]

17. Rehman, U.; Khan, S.; Muhammad, S. Ingestion of arsenic-contaminated drinking water leads to health risk and traces in human biomarkers (hair, nails, blood, and urine), Pakistan. Expo. Health 2020, 12, 243-254. [CrossRef]

18. Wu, C.; Fang, C.; Wu, X.; Zhu, G. Health-risk assessment of arsenic and groundwater quality classification using random forest in the yanchi region of Northwest China. Expo. Health 2020, 12, 761-774. [CrossRef]

19. Apollaro, C.; Di Curzio, D.; Fuoco, I.; Buccianti, A.; Dinelli, E.; Vespasiano, G.; De Rosa, R. A multivariate non-parametric approach for estimating probability of exceeding the local natural background level of arsenic in the aquifers of Calabria region (Southern Italy). Sci. Total Environ. 2022, 806, 150345. [CrossRef]

20. Figoli, A.; Fuoco, I.; Apollaro, C.; Chabane, M.; Criscuoli, A. Arsenic-contaminated groundwaters remediation by nanofiltration. Sep. Purif. Technol. 2019, 238, 116461. [CrossRef]

21. Matschullat, J. Arsenic in the geosphere-A review. Sci. Total Environ. 2000, 249, 297-312. [CrossRef]

22. Polizzotto, M.L.; Harvey, C.F.; Li, G.; Badruzzman, B.; Ali, A.; Newville, M.; Sutton, S.; Fendorf, S. Solid-phases and desorption processes of arsenic within bangladesh sediments. Chem. Geol. 2006, 228, 97-111. [CrossRef]

23. Smedley, P.L.; Kinniburgh, D.G. A review of the source, behaviour and distribution of arsenic in natural waters. Appl. Geochem. 2002, 17, 517-568. [CrossRef]

24. Drahota, P.; Filippi, M. Secondary arsenic minerals in the environment: A review. Environ. Int. 2009, 35, 1243-1255. [CrossRef] [PubMed]

25. Fuoco, I.; De Rosa, R.; Barca, D.; Figoli, A.; Gabriele, B.; Apollaro, C. Arsenic polluted waters: Application of geochemical modelling as a tool to understand the release and fate of the pollutant in crystalline aquifers. J. Environ. Manag. 2022, $301,113796$. [CrossRef]

26. Cao, W.; Guo, H.; Zhang, Y.; Rong, M.; Zhao, R. Controls of paleochannels on groundwater arsenic distribution in shallow aquifers of alluvial plain in the Hetao Basin, China. Sci. Total Environ. 2017, 613-614, 958. [CrossRef]

27. Guo, H.M.; Wen, D.G.; Liu, Z.Y.; Jia, Y.F.; Guo, Q. A review of arsenic-rich groundwater in Mainland and Taiwan, China: Distribution, characteristics and geochemical processes. Appl. Geochem. 2014, 41, 196-217. [CrossRef]

28. Shen, Y.F.; Sun, D.J.; Zhao, X.H.; Yu, G.Q. Screening report in areas of endemic arsenism and high content of arsenic in China. Chin. J. Endem. 2005, 24, 172-175. Available online: http:/ / en.cnki.com.cn/Article_en/CJFDTOTAL-ZDFB20050200N.htm (accessed on 22 October 2020).

29. Jin, Y.L.; Liang, C.K.; He, G.L.; Cao, J.X.; Ji, R.C. Study on distribution of endemic arsenism in China. J. Hyg. Res. 2003, 32, 519-540. [CrossRef]

30. Smedley, P.L.; Zhang, M.; Zhang, G.; Luo, Z. Mobilisation of arsenic and other trace elements in fluviolacustrine aquifers of the Huhhot Basin, Inner Mongolia. Appl. Geochem. 2003, 18, 1453-1477. [CrossRef]

31. Guo, H.; Yang, S.; Tang, X.; Li, Y.; Shen, Z. Groundwater geochemistry and its implications for arsenic mobilization in shallow aquifers of the Hetao Basin, Inner Mongolia. Sci. Total Environ. 2008, 393, 131-144. [CrossRef] [PubMed]

32. Deng, Y.; Wang, Y.; Teng, M. Isotope and minor element geochemistry of arsenic-rich groundwater from Hangjinhouqi, the Hetao Plain, Inner Mongolia. Appl. Geochem. 2009, 24, 587-599. [CrossRef]

33. Gong, Z.; Lu, X.; Watt, C.; Bei, W.; He, B.; Mumford, J.; Ning, Z.; Xia, Y.; Le, X.C. Speciation analysis of arsenic in groundwater from Inner Mongolia with an emphasis on acid-leachable particulate arsenic. Anal. Chim. Acta 2006, 555, 181-187. [CrossRef] 
34. Jun, H.E.; Teng, M.A.; Deng, Y.; Yang, H.; Wang, Y. Environmental geochemistry of arsenic-rich groundwater at western Hetao plain, Inner Mongolia. Front. Earth Sci. China 2009, 3, 63. [CrossRef]

35. Lin, N.F.; Tang, J.; Bian, J.M. The study on environmental geo-chemical characteristics in Arseniasis Area in the Inner Mongolia World Geol. 1999, 18, 83-88. Available online: http:/ / en.cnki.com.cn/Article_en/CJFDTOTAL-SJDZ902.011.htm (accessed on 22 October 2020).

36. Gao, C.R.; Chao-Xin, L.I.; Zhou, X.H.; Liu, B.; Liu, W.B.; Cai, L.I.; Feng, D.Y. Occurrence and hydrochemical characteristics of As-rich groundwater in the Linhe district of the Hetao Plain. Hydrogeol. Eng. Geol. 2008, 35, 22-28. [CrossRef]

37. Gao, C.; Liu, W.; Feng, C.E.; Chen, Y.; Zhang, G.; Song, J. Research on the formation mechanism of arsenic-rich groundwater in arid and semi-arid regions: A case study of Hetao Plain in Inner Mongolia, China. Earth Sci. Front. 2014, 21, 13-29. [CrossRef]

38. Jia, L.; Zhang, X.; Ye, P.; Zhao, X.; He, Z.; He, X.; Zhou, Q.; Li, J.; Ye, M.; Wang, Z.; et al. Development of the alluvial and lacustrine terraces on the northern margin of the Hetao Basin, Inner Mongolia, China: Implications for the evolution of the Yellow River in the Hetao area since the Late Pleistocene. Geomorphology 2016, 263, 87-98. [CrossRef]

39. Guo, H.; Zhang, Y.; Xing, L.; Jia, Y. Spatial variation in arsenic and fluoride concentrations of shallow groundwater from the town of Shahai in the Hetao basin, Inner Mon-golia. Appl. Geochem. 2012, 27, 2187-2196. [CrossRef]

40. Guo, H.; Liu, Z.; Ding, S.; Hao, C.; Xiu, W.; Hou, W. Arsenate reduction and mobilization in the presence of indigenous aerobic bacteria obtained from high arsenic aquifers of the hetao basin, inner mongolia. Environ. Pollut. 2015, 203, 50-59. [CrossRef]

41. Deng, Y.; Wang, Y.; Ma, T.; Gan, Y. Speciation and enrichment of arsenic in strongly reducing shallow aquifers at western hetao plain, northern china. Environ. Geol. 2009, 56, 1467-1477. [CrossRef]

42. Ni, P.; Guo, H.; Cao, Y.; Jia, Y.; Jiang, Y.; Zhang, D. Aqueous geochemistry and its influence on the partitioning of arsenic between aquifer sediments and groundwater: A case study in the northwest of the Hetao Basin. Environ. Earth Sci. 2016, 75, 356.1-356.13. [CrossRef]

43. Wang, M. Quaternary Sedimentary and Structure Features of the Hohholt-Baotou Basin, Inner Mongolia. Master's Thesis, China University of Geosciences, Beijing, China, 2006. (In Chinese with English Abstract)

44. Xiang, H.; Deng, H.; Zheng, C.; Cao, G. Hydrogeochemical signatures and evolution of groundwater impacted by the bayan obo tailing pond in northwest china. Sci. Total Environ. 2016, 543, 357-372.

45. Fang, L. Groundwater Monitoring Comprehensive Report from 2001 to 2005 in Baotou City; Inner Mongolia Institute of Geological Environment Monitoring: Hohhot, China, 2006.

46. Guo, H.; Zhang, B.; Li, Y.; Berner, Z.; Tang, X.; Norra, S.; Stüben, D. Hydrogeological and biogeochemical constrains of arsenic mobilization in shallow aquifers from the Hetao Basin, Inner Mongolia. Environ. Pollut. 2011, 159, 876-883. [CrossRef]

47. Wang, Y.; Guo, H.; Yan, S. Geochemical Evolution of Shallow Groundwater Systems and Their Vulnerability to Contaminants: A Case Study at Datong Basin, Shanxi Province; Science Press: Beijing, China, 2004; p. 62. (In Chinese)

48. Goldberg, S. Chemistry of the solid-water interface: Processes at the mineral-water and particle-water interface in natural systems. Geochim. Cosmochim. Acta 1992, 57, 205. [CrossRef]

49. Smedley, P.L.; Kinniburgh, D.G.; Macdonald, D.; Nicolli, H.B.; Barros, A.J.; Tullio, J.O. Arsenic associations in sediments from the loess aquifer of la pampa, argentina. Appl. Geochem. 2005, 20, 989-1016. [CrossRef]

50. Li, P.; Zhang, Y.; Yang, N.; Jing, L.; Yu, P. Major ion chemistry and quality assessment of groundwater in and around a mountainous tourist town of China. Expo. Health 2016, 8, 239-252. [CrossRef]

51. Li, P.; Tian, R.; Liu, R. Solute geochemistry and multivariate analysis of water quality in the Guohua Phosphorite Mine, Guizhou Province, China. Expo. Health 2019, 11, 81-94. [CrossRef]

52. Ren, X.; Li, P.; He, X.; Su, F.; Elumalai, V. Hydrogeochemical processes affecting groundwater chemistry in the central part of the Guanzhong Basin, China. Arch. Environ. Contam. Toxicol. 2021, 80, 74-91. [CrossRef] [PubMed]

53. Wu, J.; Li, P.; Wang, D.; Ren, X.; Wei, M. Statistical and multivariate statistical techniques to trace the sources and affecting factors of groundwater pollution in a rapidly growing city on the Chinese Loess Plateau. Hum. Ecol. Risk Assess. 2020, 26, 1603-1621. [CrossRef]

54. Wu, J.; Li, P.; Qian, H.; Duan, Z.; Zhang, X. Using correlation and multivariate statistical analysis to identify hydrogeochemical processes affecting the major ion chemistry of waters: Case study in Laoheba phosphorite mine in Sichuan, China. Arab. J. Geosci. 2014, 7, 3973-3982. [CrossRef]

55. Zhang, Y.; Cao, W.; Wang, W.; Dong, Q. Distribution of groundwater arsenic and hydraulic gradient along the shallow groundwater flow-path in hetao plain, northern china. J. Geochem. Explor. 2013, 135, 31-39. [CrossRef]

56. Wang, Y.X.; Su, C.L.; Xie, X.J.; Xie, Z.M. The genesis of arsenic-rich groundwater:a case study in Datong basin. Geol. China 2010, 37, 771-780. [CrossRef] 